\title{
高年者の網膜血管と脳，心，腎細小血管 との関連性に就いて
}

\author{
日本医科大学眼科学教室 (主任 桶渡正五教授) \\ 韋宛鳥 \\ 斑 \\ Enhan Ii
}

\section{I 緒 言}

今次大戦後 Penicillin を初めとする各種抗生物質 の発見が細菌性諸疾患に卓効を奏する事が明白とな り,ひいては人間の寿命が著しく延長するに到つ た。嘗て数十年前には 50 才代で既に翁と呼ばれた当 時の人間の平均寿命を今日の夫れと比較すれば将に隔 世の感がある。然し同時に初老以後の人々の最も恐れ る所のものは脳卒中であり, 心疾思による突然の死で あつて, 之等の多くは高血圧や動脈硬化症に基く場合 が多い。従つて高血圧症や動脈硬化症が関心の対象と なると同時に、之等の結果を惹起する原因の考察や， 之等と関係の深いと思われる各種の筒疾患, 心疾患及 び脳疾患, 殊に夫々の臓器の細動脈の変化が眼底細動 脈の硬化所見と如何に関係するか, 又眼底血圧並びに 全身血圧と如何に密接に結びついているかを知る事 は, 眼科領域に於て眼底血管を中心として考える場 合，特に関心の払われる所である。

一般に高年者は血圧の亢進している例が多いから，

腎動脈の硬化や筒萎縮の程度が注目せられることにな る。外観的に健康でも䴛機能に多くの変化をみる事は 高年者に震々認められる所であり, 濃縮試験排尿試験 等の成績も考慮せられる事になる。

高年者の心冠動脈の硬化や心電図所見の異常之網膜 血管硬化度との関連性も, 眼底血管が我々の肉眼的観 察の直接対象となる点より考えて, 殊江興味をひく点 である。

脳血管殊にその細小動脈と眼底血管硬化の関連性に 就いては, 両者が内頸動眽より出発する点等を思えば 数多くの文献をみることも当然である。然し之等の多 くは老若者を悉く含めての高血圧を中心とする研究が 大多数で特に高年者を中心とする研究は甚だ少く, 僅 かに桶渡教授及びその門下を中心とする研究のみで， 欧米では Rintelen の数十例の剖検例其の他少数に過 ぎな。よつて著者は之等 4 者間の関係を検索し，い ささか芫る可き知見を得たので報告する次第である。
元来この研究は臨床的観察, 剖検所見との比較, 病理 組織学的所見の 3 篇に分たれているのであるが, 紙面 の都合上 1 篇に縓めて報告する。

\section{II 文献的考察}

眼底血管の硬化と脳血管の硬化, 腎細小動脈の硬化 及び心冠状動脈の硬化との諸関係を夫々別個に観察し た文献は高血圧や動脈硬化が比較的強い関心の対象と なつているにも拘らず, 案外に少いのである。

動脈硬化症は動脈の消耗症で年令の増加に伴つて一 般に増加するのであるが，血管変化は全身に必らずし も平等には起るものでなく, 又本症の際の症状は霍患 部位の如何で相違するが, 内科的には㮦骨動脈, 上膊 動脈, 大腿動脈, 䫑㛲動脈等でその存在を知る。硬化 があれば血管の蛇行や搏動をみる事があり, 緊張が増 加して管壁の肥厚を触知し得, 血管によつては肥厚と 硬化沫加えて汎発性拡張を認める場合や蛇行を知る事 あある。本症の際の血圧に関しては Romberg, 沢田等 は動脈硬化の中 $12.5 \%$ 位飞血圧は艺進するといい, Gradel, Dunin は慢性腎炎のない動脈硬化中約 1/3 に高血圧があるとし，Thayer，Israel は腸チブス霍患 後の本症患者は相当年令の健康人より血圧が高いと述 ベている。

動脈硬化並びに血圧元進は必然に左室の肥大、心壁 の肥厚を招来し, 二次的に各機能的器質的変化を心藏 そ来たすと共に, 䐌では細小動脈以上の動脈の変化と 多尿及び夜尿時の蛋白が証明せられることもあるが， 高度の機能障害は稀であるとされている。脈搏は通常 持続的に増加するといわれる。又脳動脈のみが硬化に 陥ることすあり，心，腎の硬化と同時に来ることも暦 々あるといわれる。

動脈硬化症の原因は Marchand, Johres 等の器械的 労使による血管壁消耗説の外飞遗伝的要素もあり, 急 性伝染病, 化学的有害物の作用による場合るあると考 えられている。

特発性高血圧症: Huchard, Alburt 等が動脈硬化 
症や腎疾患がなく高血圧のみが主である疾患を報告し て以来，多くの報告が相次ぎ，Frankは之を本態的血 圧穴進症と名つけた。Kylin, Kahler 等とよると本症 は植物神経系機能障害による諸徴候を有し中枢性乃至 末梢神释作用或いは化学的作用を主因とすると考兄ら れ, 遗伝的体質的関係, 新陳代謝内分必異常, 中毒, 精神的興典等をも誘因となり得るが，とに角本症が血 管運動神释異常に基く全身細小動脈の緊張穴進乃至獎 縮で高血圧を招来し, 初期には器質的変化はないが, 病状が進行すると硬化性変化が細小動脈壁に及び所謂 広義の動脈硬化症に移行する故, 本症は初期の「ノイ ローゼ」症候の主な時期と動脈硬化の加わつた後期に 分たれ恒久性となり自覚症状として様々の変化が起 り, 後には腎及び脳動脈硬化から, 軽度蛋白尿や眼底 出血を起し易くなり, 脳出血, 心衰弱, 萎縮腎, 尿毒 症等で制れるにいたる。

眼底所見として植村教授は網膜動脈の異常な狭細と 管壁の混濁を, 又黄斑部の変化を述へ，菅沼は網膜混 濁を，Barlow は網膜動眽の㹨細と黄斑部の菊花状白 斑の例, Brana, Schiff 等は網膜動眽の硬化性変化と 血圧光進度の不一致を記し, Horine, Weiss も主変化 としての小動脈の変化を記載している。Schieck は本 症飞於ける病変を 2 型飞分ち, 辻は又本症の潜代期に 於ける全例にみられる細小血管の拡大迂曲蛇行と運動 後の毛細血管博動の原因を細小静脈管壁の滑平筋の脆 弱性飞㴆し, 本症の本態は異常体質としての心筋及び 血管滑平筋の先天的劣質にあるといつている。菅沼は 本症の網膜血管血圧を測定し，本症の血圧六進を留性 の場合や全身的動脈硬化症時の夫れと比較した。長谷 部も同様に本症の網膜血管血圧を測定し, 血圧光進は 可なり著明であるが，血管硬化は充分証明し得奴場合 る展々であつたと述へて居り, 鴨川は本症の体位変動 時の網膜血管血圧を測定し, 水平仰卧位に移つた直後 の血圧上昇は健康者に比して遙かに高いとした。 Guist は本症患者の網膜細小静脈中, 黄斑部に向うも のは「コルク」栓抜様の迂曲蛇行を示し, 之が腎性高 血圧症との鑑别診断に役立つとし, $\mathrm{Pal}$, 金等は之に 賛成しているが, Sallmann, Kahler 等は本現象が本 症の必発症状ではないと述へている。

腎性高血圧症：Volhard, Fahr, Kylin, Ricker, Kahler 等の研究による原因論，本態論を別として， 眼科的任重要なのは慢性腎炎，原発性又は続発性萎縮 腎, 或いは動脈硬化性菱縮筲等がある。血圧の亢進は 著明で動摇少く最低 100 , 最高 200 以上の事は稀でな
い。この際の眼底所見は極めて特有で人によつては軽 度の視力障害と頭痛で看過されていたものが, 眼底検 查によつてその重篤な事を発見される場合る稀ではな い。即ち特有とする網膜病変と血管の硬化即ち視神経 乳頭の発赤と混濁, 網膜の浮腫状混濁と出血白斑中黄 斑部の星艺斑の外, 動脈の細之血管䇒の肥厚混濁, 血柱反射の増強や各種の交叉現象に関してはその病理 組織学的研究と共に既飞小楖教授の詳報した所であ り, 其の他植村, 营沼, 飯塚, 進藤等の諸氏も本症の 網膜血管硬化像が動脈硬化性網膜炎時のそれと殆んど 異る所がないと述へている。本症の初期飞漿液性中心 性網膜炎が起り, 黄斑部反射飞異常ある事をWolff は 述べ, 小口る初期症候としての所見としてWolff に 賛成している。長谷部, 菅沼は本症の網膜中心動脈血 圧が異常に光進している者の予後の不良なことを述へ ている他, 所調蛋白尿性網膜炎に関する文献は内外之 すに実に夥しい数にのぼつているが，その本態は今尚 甲論乙駁の有様である。

局所性頭蓋内高血圧症 : 1931 年 Espildora は BaiIliart の眼底血圧計飞よつて網膜血管血圧を測定した 結果, 血圧六進症を全身の血圧方進を伴万るのと然ら ざるものとと区別した。即ち上膊動脈血圧が正常で網， 膜中心動脈血圧の異常な六進例を揭げ, この際の自覚 症状として飛蚊症, 光視症, 閃輝性暗点症等を有する ものと脳症状を有するすのを掲げて，網膜中心動脈血 圧亢進に種類を分ち、脳内圧や全身血圧の六進がない のと網膜血管血圧が元進する事は血管系統の障害の存 在を意味するから重大であると述べた。菅沼, 鴨川る 局所性頭蓋内血圧元進症㭧者に於ける網膜中心動脈血 圧やそれの体位による変動を研究して, 本症の大多数 飞眼底血管の督縮を認め, 中心動脈血圧が全身血圧に 対して 0.65 以上のものが半分以上であり, 坐位から 水平仰臥位に転ずると相当に著しい血圧上昇が認めら れると述べている。

以上の研究は大多数が若年者から高年者に至る迄の 症例を含み, 且つその例数が比較的少い点から考兵る 時, 最近の研究として文苚上に見られる日本の文献で は老年者に関しては中泉, 小松, 樋渡, 百瀬等数氏の 研究に過ぎない。そして之等の研究の中心は眼底血管 を中心とする硬化と眼底血圧全身血圧との較研究方 大 部分で他脿器血管との比較や剖検時の比較研究は桶渡 教授の文献が最近現われたのみである。

III 実験材料と実験方法

実験材料は 60 才以上の高年者約 500 例であつて。 
日常生活は極めて満足す可き環境下に生活した男女を とつた。即ち東京都及び中華民国台湾省台南市に於け る症例数であつて, 之等の高年者を血圧の如何に拘ら ず，軽度のトラコーマや結膜炎及び軽度白内障等はあ つても眼底検査を行うに差支えない者は悉く検査を施 行した。然し実験材料の多い為，初めは行なわなかつ た検査も後には追加されたり，眼底検査は出来ても， 眼底血圧の測定が不確実であつた者等の為に各統計的 検査項目の場所では之等を除外するの止むなきに到つ たものもあつて検查項目に於ては症例数に多少の相違 のある所がある。

即ち 60 才以上の高年者の生前に於ける全身眼底両 血圧, 眼底所見（主として眼底血管の硬化化の外，眼 底出血白斑や其他の老人性変化等を含む）を繰返し観 察測定した後，心電図検査は単極誘導法を用い，留機 能検査としては尿蛋白の測定定性を早朝尿で薏沸試験 と Sulfosalicyl 試験で行い, P.S.P 試験の他, 残余 公素は全血を用いFolin-Wu 氏法を，稀釈及び濃縮 試験はVolhard 氏法で時間の排尿量と比重の測定を 行つた。死後剖検に際しては脳血管にあつては, 脳基 底動脈, 前脳中脳後脳動派飞就いて, 心変化は冠動脈 の硬化, 狭窄, 閉塞, 左心室の肥大と拡張, 心筋の混 濁, 胼胝壊死及び梗塞を, 腎藏に於ては腎動脈の硬化 と挔張と㹨窄，平滑並びに粗大及び細顆粒萎縮，真性 萎縮と老人性萎縮に就いて検討した後, 摘出した眼球 は $10 \%$ フォルマリン固定後, ツェロィシン包埋を行 つた後, 水平矢状断によつて切片標本を作製した後, ヘマトキシリンーエオジン染色, ワンギーソン染色並 びにマザンマロリ一染色法を用いて之を行い心，腎， 脳血管はパラフィン包埋を行つた。

\section{IV 実験成績}

1）年令別及び性別（第 1 表）

実験に用いた材料の男女別は男子 102 例 (33.1\%)， 女子 206 例 (66.9\%) で合計 308 例である。年令は悉 く60才以上で 60 才代 65 例 (21.1\%)，70才代 162 例 (52.5\%)，80才代 72 例 (24.7\%) で90才代は僅か

第 1 表 年企別及び性別数

\begin{tabular}{c|rr|rr|rr}
\hline 年 令 & \multicolumn{2}{|c|}{ 男 } & \multicolumn{2}{|c|}{ 女 } & \multicolumn{2}{|c}{ 計 } \\
\hline $60 \sim 69 才$ & 28 & $(9.1)$ & 37 & $(12.0)$ & 65 & $(21.1)$ \\
$70 \sim 79 才$ & 53 & $(17.2)$ & 109 & $(35.4)$ & 162 & $(52.5)$ \\
$80 \sim 89 才$ & 20 & $(6.5)$ & 56 & $(18.2)$ & 72 & $(24.7)$ \\
90 才以上 & 1 & $(0.3)$ & 4 & $(1.3)$ & 5 & $(1.6)$ \\
\hline 計 & 102 & $(33.1)$ & 206 & $(66.9)$ & $308(100.0)$ \\
\hline
\end{tabular}

第 2 表 剖検例直接死因

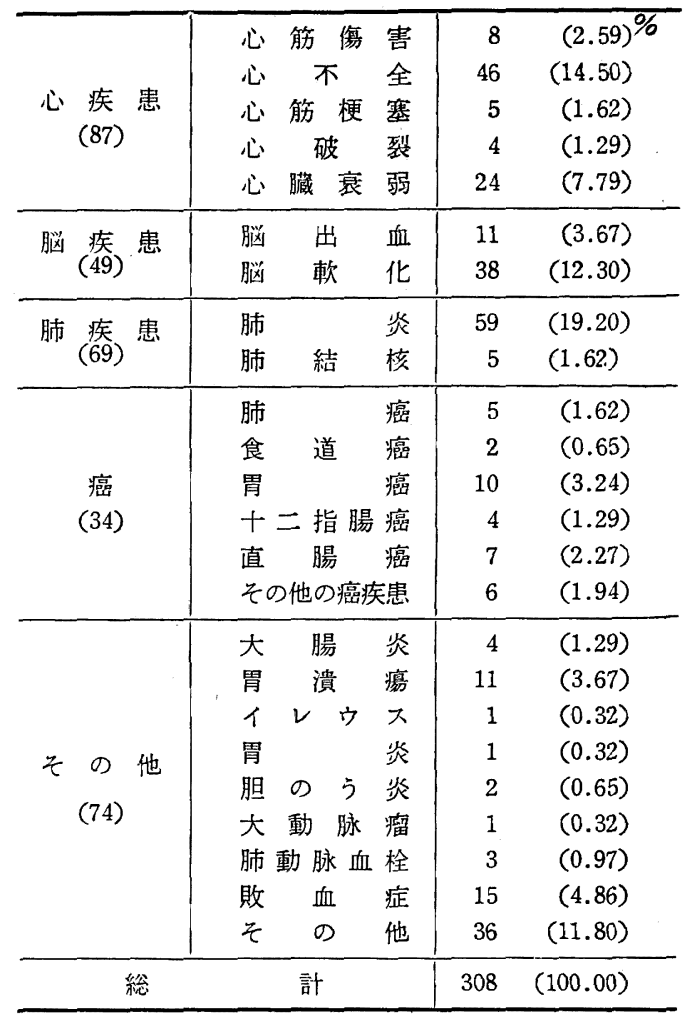

飞 5 例 (1.6\%) 飞過ぎず 70 才代が全体過半数以上を 占め, 而子女子が男子の倍以上である。然し 60 才代 では男女別の差は夫程大ではない。

2）剖検による直接死因の検索（第 2 表）

上記 308 例の死亡原范を剖検の結果, 判明した直接 死因別に見た統計的結果は表の如くで，308 例中，心 疾患によるもの 87 例 (28.2\%), 脳疾患によるもの 49 例 $(15.9 \%)$, 肺疾患によるもの 69 例, 痁に基くもの 34 例, 其他か 74 例となつて居り, 腎疾患飞よる死亡 者は認められていない。

3）臨床的に脳血管に障害ありと診断された者と心 電図変化との関係（第 3 表）

臨床的に心電図を調查した 202 例中で, 生存中脳卒 中又は脳動脈硬化症等の如き脳血管障害ありとの診断 を受けた者にして，而も心電図に何等かの形で異常の あつた者が 76 例, 心電図に異常があつて子臨床的に 脳血管に障害のないと考えられた者は 52 例, 心電図 には全く異常なく, 又臨床時に脳血管障害の診断を受 けなかつた者は 37 例であり，この中高血圧すないと された者は 37 例中 28 例であつた。又臨床的に脳血管 
第 3 表 臨床的脑疾患診断と心電図变化との関係

\begin{tabular}{|c|c|c|c|c|c|}
\hline 診目 & & 腦動脉 & $\begin{array}{l}\text { 䑈に血管 } \\
き も の\end{array}$ & 管傷害な & \\
\hline & & 硬化症 & $\begin{array}{l}\text { 高血圧の } \\
\text { あるもの }\end{array}$ & 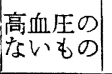 & 計 \\
\hline 筋障害 & $42(20.7)$ & $8(3.94)$ & $11(5.43)$ & $16(7.4)^{\%}$ & \\
\hline 心室肥大 & $10(4.94)$ & - & $1(0.49)$ & $8(3.95)$ & 19 \\
\hline 筋 梗塞 & $5(2.47)$ & $1(0.49)$ & $2(0.98)$ & $5(2.47)$ & $13(6.43)$ \\
\hline 脚プロック & $6(2.96)$ & $1(0.49)$ & $1(0.49)$ & $4(1.97)$ & $12(5.92)$ \\
\hline 洞性速脉 & $2(0.98)$ & $1(0.49)$ & - & $4(1.97)$ & $7(3.46)$ \\
\hline $\begin{array}{l}\text { 異常なき } \\
\text { な }\end{array}$ & $29(14.3)$ & $8(3.95)$ & $9(4.45)$ & $28(13.8)$ & $74(36.5)$ \\
\hline 計 & $94<46$. & & & & \\
\hline
\end{tabular}

第 4 表”直接死因が心変化によるものの 䂑床的脳疾患症例数

\begin{tabular}{|c|c|c|c|}
\hline 脳 & 中 & 34 & $(39.2)^{\%}$ \\
\hline 䑈 動 脉 & 硬 化 症 & 9 & $(10.4)$ \\
\hline \multirow{2}{*}{$\begin{array}{l}\text { 脳に血管性 } \\
\text { 傷害のないもの }\end{array}$} & 高血圧のあるもの & 11 & $(12.6)$ \\
\hline & 高血圧のないもの & 33 & $(38.0)$ \\
\hline \multicolumn{2}{|l|}{ 総 } & 87 & $(100.0)$ \\
\hline
\end{tabular}

障害の診断を受け乍らも，心電図に全く異常のない者 は 37 例であつた。

4）直接の死因が心㵶疾思にありとされた者の臨床 的並びr剖検的統計成績

前述の如くに直接死因としては心疾患, 脳疾患其の 他はあつても腎疾患はない所から私はこの直接死因別 にして脳血管及び腎血管との関係を調べる事にした。

a）之等 87 例が生存中脳血管障害があつたか無か つたかを調べて見ると，脳卒中が 34 例 (39.2\%) 脳 動脈硬化症 9 例 (10.4\%) であり，少くとも生存中脳 血管障害の診断を受けなかつた者は44例であつて，ほ ぼ相半ばしていると思われる。（第 4 表）

b） i ）心疾㭧飞よる死亡者の臨床的脳血管障害の 有無と全身眼底血圧及び眼底所見との関係。

87例のこの脳血管の臨床的喨断所見と眼底全身両血 圧及び眼底血管の硬化度とを較べて見ると，脳血管に 障害ありとされた者は悉く網膜血管の硬化度は中等度 と高度の者のみである外, たと充生存中脳血管に障害 を起さなかつた者でも高血圧のあつた者は矢張り網膜 血管の硬化は悉く強い者のみであつた。又全く同様の 事が眼底血圧の最高最低血圧の場合飞就いても言壳る 事が判明した（第 5 表）。

ii）心疾思による死亡者の全身眼底両血圧及び眼底 血管硬化度と, 剖検による脳血管硬化度との関係。
第 5 表 心疾患による死亡者の臨床的脳血管傷害と 血圧及び脳底所見との関係

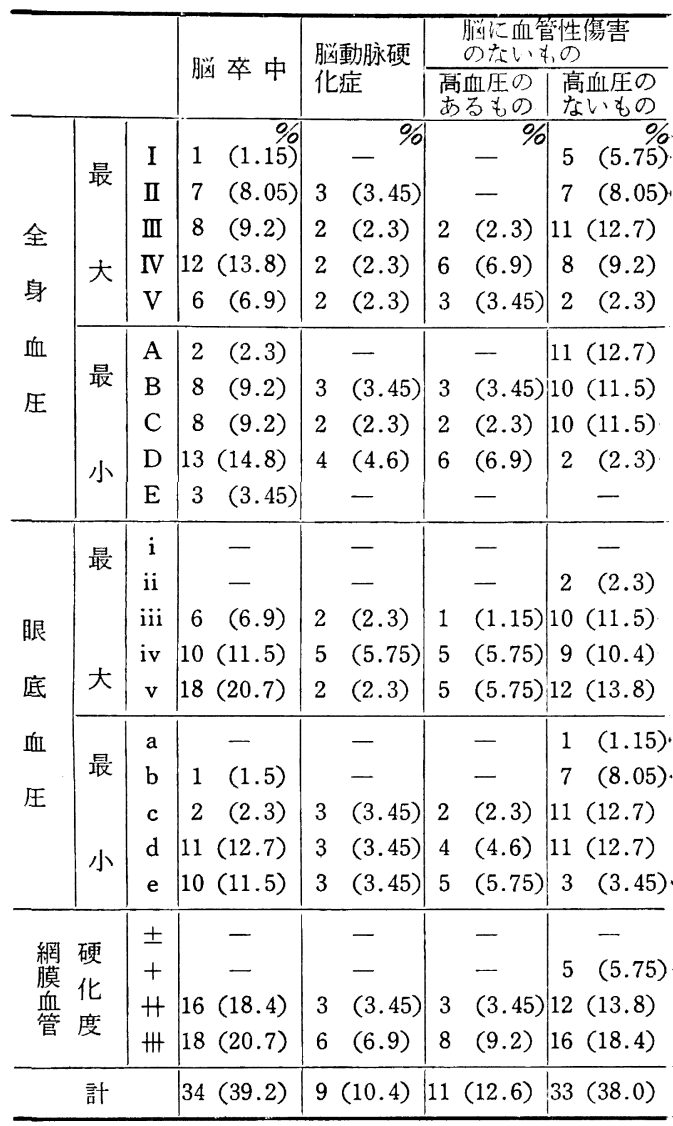

第 6 表に示す如く, 基底動脈, 中脳, 前脳, 後脳動 脈の剖検記録と全身眼底両血圧が悉く測定された者の みを比較すると, 基底動脈の硬化中等度以上で網膜血 管硬化が中等度以上の者は 84 例中 45 例，50\%以上を 占め, 中脳動脈之網膜血管では俱に硬化中等度以上は 46 例中 30 例 $(65.2 \%)$ である。後脳動脈と網膜血管 では中等度硬化以上は 44 例中 15 例 $(34.09 \%)$, 前脳 動脈之網膜血管での夫れは 46 例中 8 例 (17.39\%) で, 中脳, 脳基底, 後脳前脳動脈の順序に硬化が減少 してりく様子がみられ，知張り同様なことは眼底血圧 の高い者には中脳基底動脈の硬化の強い者が多く，前 脳動脈では血圧殊飞眼底血圧と前脳動脈硬化度との間 には殆んど関連性はみとめられない。

c）全身眼底両血圧, 網膜血管硕化度と筒所見との 關係。

之の関係の中, 臨床的の諸检查, 殊に生存中の沜縮 武騃, 排尿試験, P.S.P 試㖘に就いては諸検査を前述 
第6表心疾患死亡者の脳血管所見と

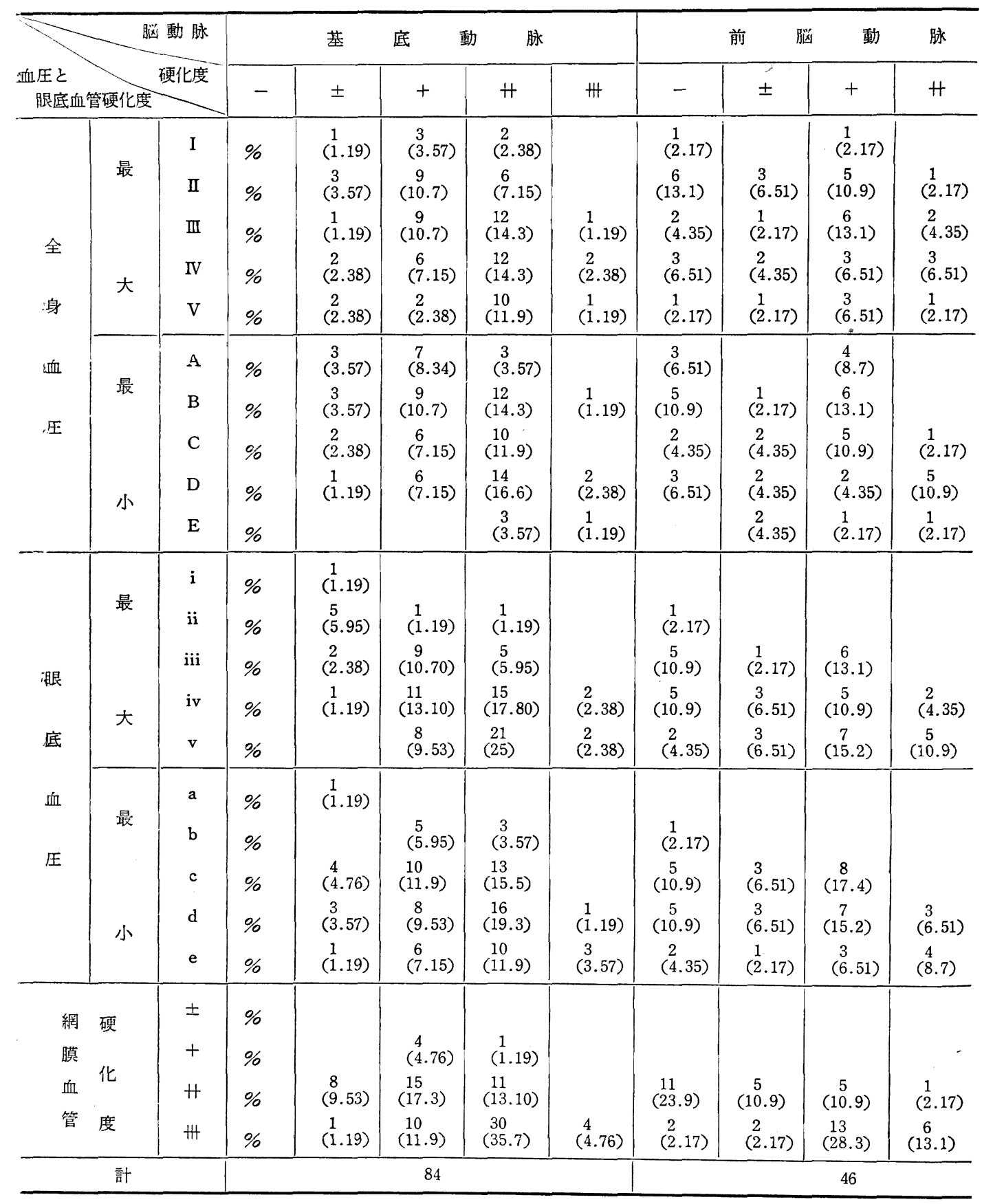


血圧及び眼底所見との関係

\begin{tabular}{|c|c|c|c|c|c|c|c|c|c|c|}
\hline & & 中 & 動 & 脉 & & & 後 & 脳 & 脉 & \\
\hline H & - & \pm & + & H & m & - & \pm & + & H & $\mathrm{W}$ \\
\hline$\stackrel{1}{(2.17)}$ & $\underset{(4.35)}{2}$ & $\begin{array}{l}\frac{1}{(2.17)} \\
2 \\
(4.35)\end{array}$ & $\begin{array}{c}1 \\
(2.17) \\
5 \\
(10.9) \\
3 \\
(6.51) \\
1 \\
(2.17) \\
1 \\
(2.17)\end{array}$ & $\begin{array}{c}4 \\
(8.7) \\
7 \\
(15.2) \\
4 \\
(8.7) \\
4 \\
(8.7)\end{array}$ & $\begin{array}{c}3 \\
(6.51) \\
2 \\
(4.35) \\
5 \\
(10.9) \\
1 \\
(2.17)\end{array}$ & $\begin{array}{l}2 \\
(4.55) \\
\\
\stackrel{3}{(6.82)}\end{array}$ & $\begin{array}{l}1 \\
(2.27) \\
2 \\
(4.55) \\
\\
\\
(2.27)\end{array}$ & $\begin{array}{c}1 \\
(2.27) \\
8 \\
(18.2) \\
7 \\
(15.9) \\
1 \\
(2.27) \\
3 \\
(6.82)\end{array}$ & $\begin{array}{c}3 \\
(6.82) \\
3 \\
(6.82) \\
6 \\
(13.6) \\
3 \\
(6.82)\end{array}$ & \\
\hline $\begin{array}{l}1 \\
(2.17)\end{array}$ & $\begin{array}{l}(1 \\
(2.17) \\
1 \\
(2.17)\end{array}$ & $\begin{array}{l}1 \\
(2.17) \\
2 \\
(4.35)\end{array}$ & $\begin{array}{c}4 \\
(8.7) \\
3 \\
(6.51) \\
2 \\
(4.35) \\
2 \\
(4.35)\end{array}$ & $\begin{array}{c}2 \\
(4.35) \\
5 \\
(10.5) \\
6 \\
(13.1) \\
5 \\
(10.9) \\
1 \\
(2.17)\end{array}$ & $\begin{array}{c}1 \\
(2.17) \\
3 \\
(6.51) \\
1 \\
(2.17) \\
5 \\
(10.9) \\
1 \\
(2.17)\end{array}$ & $\begin{array}{l}3 \\
(6.82) \\
2 \\
(4.55)\end{array}$ & $\begin{array}{l}2 \\
(4.55) \\
1 \\
(2.27) \\
\\
1 \\
(2.27)\end{array}$ & $\begin{array}{c}5 \\
(11.4) \\
6 \\
(13.6) \\
5 \\
(11.4) \\
4 \\
(9.1)\end{array}$ & $\begin{array}{c}4 \\
(9.1) \\
3 \\
(6.82) \\
6 \\
(13.6) \\
2 \\
(4.55)\end{array}$ & \\
\hline $\begin{array}{l}1 \\
(2.17)\end{array}$ & $\begin{array}{l}1 \\
(2.17) \\
1 \\
(2.17)\end{array}$ & $\begin{array}{c}1 \\
(2.17) \\
2 \\
(4.35)\end{array}$ & $\begin{array}{c}1 \\
(2.17) \\
5 \\
(10.9) \\
4 \\
(8.7) \\
1 \\
(2.17)\end{array}$ & $\begin{array}{c}5 \\
(10.9) \\
5 \\
(10.9) \\
9 \\
(19.6)\end{array}$ & $\begin{array}{c}1 \\
(2.17) \\
5 \\
(10.9) \\
5 \\
(10.9)\end{array}$ & $\begin{array}{c}3 \\
(6.82) \\
2 \\
(4.55)\end{array}$ & $\begin{array}{c}1 \\
(2.27) \\
3 \\
(6.82)\end{array}$ & $\begin{array}{c}1 \\
(2.27) \\
5 \\
(11.4) \\
7 \\
(15.9) \\
7 \\
(15.7)\end{array}$ & $\begin{array}{c}3 \\
(6.82) \\
4 \\
(9.1) \\
8 \\
(18.2)\end{array}$ & \\
\hline $\begin{array}{l}1 \\
(2.17)\end{array}$ & $\begin{array}{l}1 \\
(2.17) \\
1 \\
(2.17)\end{array}$ & $\begin{array}{l}1 \\
(2.17) \\
1 \\
(2.17) \\
1 \\
(2.17)\end{array}$ & $\begin{array}{c}1 \\
(2.17) \\
\\
\\
6 \\
(13.1) \\
3 \\
(6.51) \\
1 \\
(2.17)\end{array}$ & $\begin{array}{c}6 \\
(13.1) \\
7 \\
(15.2) \\
6 \\
(13.1)\end{array}$ & $\begin{array}{c}1 \\
(2.17) \\
7 \\
(15.2) \\
3 \\
(6.51)\end{array}$ & $\begin{array}{c}3 \\
(6.82) \\
2 \\
(4.55)\end{array}$ & $\begin{array}{l}2 \\
(4.55) \\
2 \\
(4.55)\end{array}$ & $\begin{array}{c}1 \\
(2.27) \\
\\
9 \\
9 \\
(20.5) \\
8 \\
(18.2) \\
2 \\
(4.55)\end{array}$ & $\begin{array}{c}2 \\
(4.55) \\
7 \\
(15.7) \\
6 \\
(13.6)\end{array}$ & \\
\hline \multirow[t]{2}{*}{$\stackrel{1}{(2.17)}$} & $\begin{array}{l}2 \\
(4.35)\end{array}$ & $\begin{array}{l}2 \\
(4.35) \\
1 \\
(2.17)\end{array}$ & $\begin{array}{c}9 \\
(19.6) \\
2 \\
(4.35)\end{array}$ & $\begin{array}{c}7 \\
(15.2) \\
12 \\
(26.1)\end{array}$ & $\begin{array}{c}2 \\
(4.35) \\
9 \\
(19.6)\end{array}$ & $\begin{array}{c}5 \\
(11.4)\end{array}$ & $\begin{array}{l}3 \\
(6.82) \\
1 \\
(2.27)\end{array}$ & $\begin{array}{c}11 \\
(24.97) \\
9 \\
(20.5)\end{array}$ & $\begin{array}{l}3 \\
(6.82) \\
12 \\
(17.3)\end{array}$ & \\
\hline & \multicolumn{5}{|c|}{46} & \multicolumn{5}{|c|}{44} \\
\hline
\end{tabular}


$-240-(1110)$

の方法で記した如くに施行したが，之等の関係に就い ては別飞詳紐に報告されているので，ここでは之等の 臨床検查を除き尿蛋白との関係並びと腎剖検結果との 関係を記述することにする。

i ）血圧, 網膜血管硬化度と尿蛋白との関係（第 7 表)

心疾㭧死亡者の粲所見中尿の蛋白と眼底所見を調へ てみると, 蛋白の陰性陽性及びその程度に拘らず, 網 膜血管硬化度は中等度以上の者が大多数を占めて居 $\eta$, 又全身眼底雨血圧と尿蛋白との関係では蛋白が陰 性でも全身の最大最小血圧は可なり高い者が多く, 蛋 白の陽性度が增加しても特に全身血圧で血圧の高い型 の者が増加している傾向は見られない。然し蛋白中等 度陽性 (\#) の者, 或いは中等度高度の蛋白の出現す る所では眼底血圧の高い者が相当数多く, 且つ網膜血 管硬化も高度の者が圧倒的に多数例みられて居る。

ii ）血圧, 網膜血管硬化度と粲剖検所見との関係 (第 8 表, 9 表)。
死体剖検時飞於ける腎解剖を肉眼的に観察した場 合，腎細顆粒萎縮は腎血管殊にその arteriolosklerose そ基因する結果として表現され，粗大顆粒萎縮は arteriosklerose 飞基因し，平滑萎縮は血管飞特に変 化を認めない場合の留萎縮の状態として表現されてい るのであるが，かかる肉眼的観察結果を全身眼底両血 圧及び網膜血管硬化度と比較検討するに，全身眼底両 血圧々細顆粒萎縮の程度, 又網膜血管硬化の程度と細 顆粒萎縮の程度との間には平行的関係はみられず, 粗 大顆粒葁縮と眼底全身両血圧及び網膜血管硬化度との 間, 及び平滑萎縮と血圧及び網膜血管硬化度との間に 8全く同様, 平行的な関係は見出されない。

留全体の老人性萎縮の程度と全身眼底両血圧, 網膜 血管硬化度との間や，良性の真性萎縮腎の程度と全身 眼底両血圧及び網膜血管硬化度との間には全く関係は 認められない。

太い腎動脈の硬化度と網膜血管硬化度との間飞は相 関的関係はみられない, 又全身眼底両血圧と腎動脈硬

第 7 表 直接死因が心疾患にあるものの尿蛋白と血圧及び眼底所見との関係

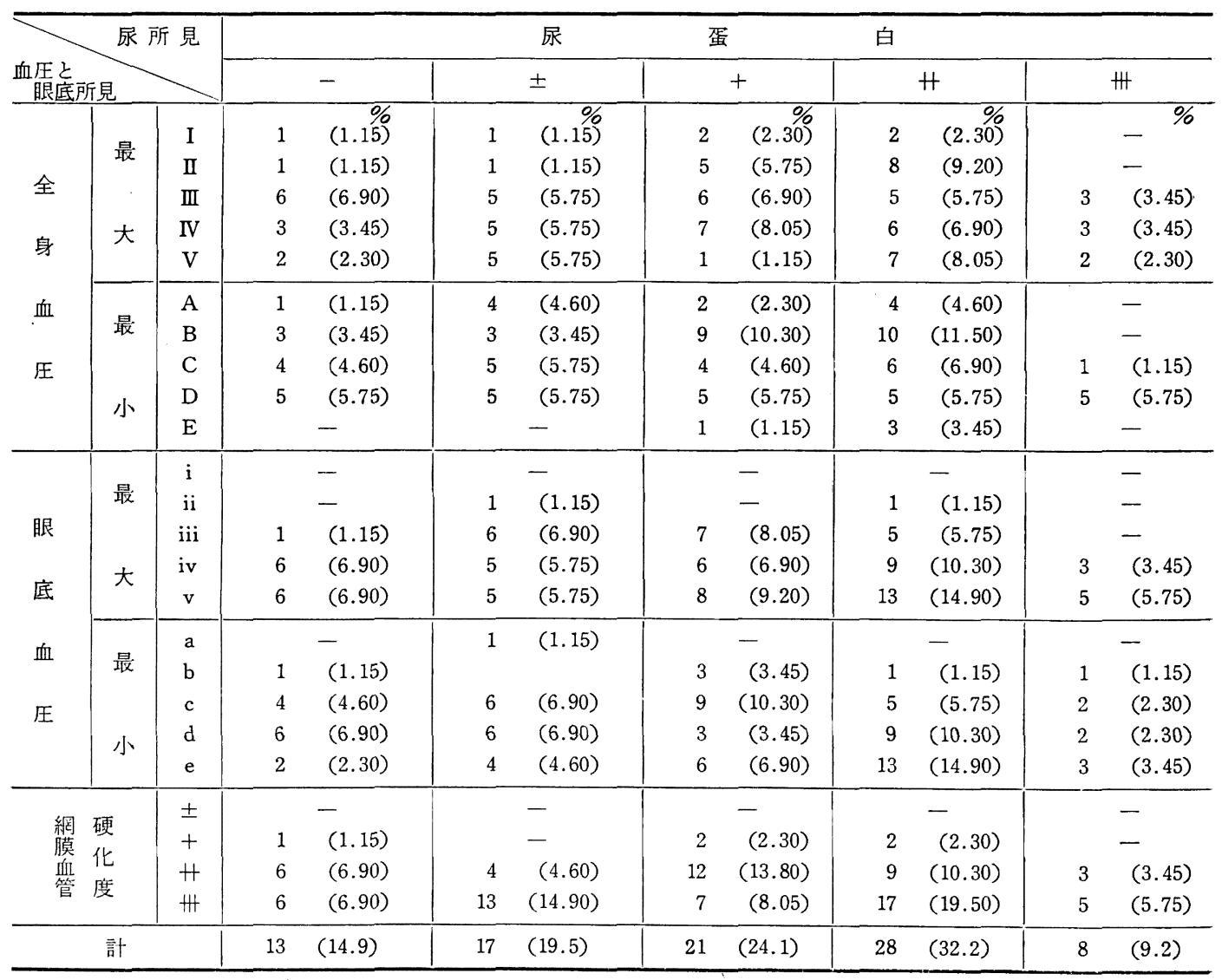


第 8 表 直接死因が心疾患にあるもも腎剖検所見と血圧及び眼底所見との関係（その 1)

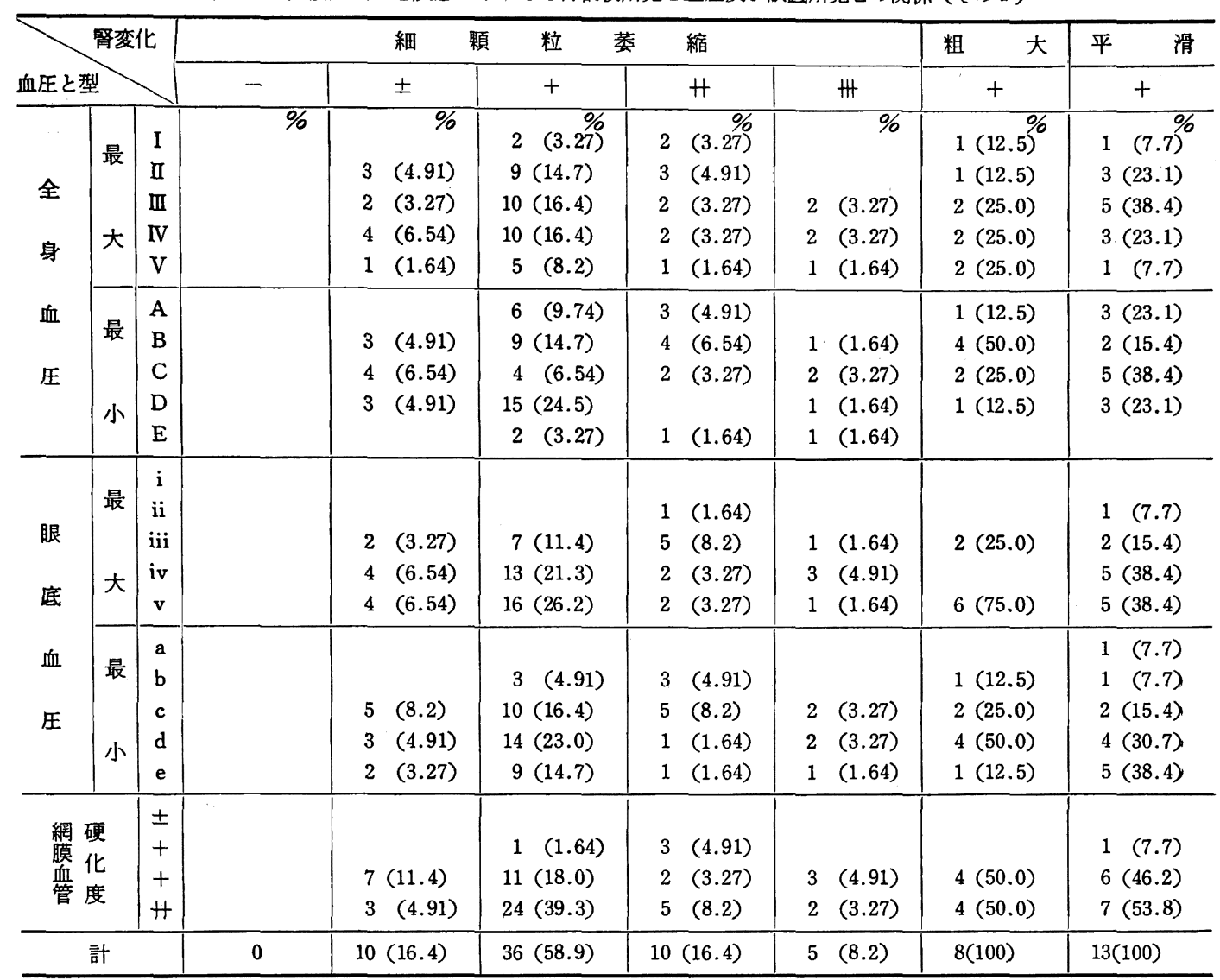

第 9 表 直接死因が心疾患にあるものの腎剖検所見と血圧及び眼底所見との関係 (その 2 )

\begin{tabular}{|c|c|c|c|c|c|c|c|c|c|c|c|c|c|c|c|}
\hline & \multicolumn{5}{|c|}{ 老人 性 萎 縮 } & \multicolumn{5}{|c|}{ 良 性 真 性 萎 縮 腎 } & \multicolumn{2}{|c|}{ 動 } & \multicolumn{2}{|l|}{ 硬 化 } \\
\hline & & - & \pm & + & H & 册 & - & \pm & + & $H$ & 册 & \pm & + & H & 世 \\
\hline \multirow{4}{*}{ 全 } & I & & & $\begin{array}{c}2 \\
(3.06)\end{array}$ & $\stackrel{2}{(3.06)}$ & & & & & $\begin{array}{l}2 \\
(4.54)\end{array}$ & \multirow{4}{*}{$\left(\begin{array}{l}. \\
1 \\
12.27)\end{array}\right.$} & & $(1.75)$ & $\stackrel{1}{(1.75)}$ & \multirow{4}{*}{$\left(\begin{array}{l} \\
1 \\
(1.75)\end{array}\right.$} \\
\hline & 最 II & I 11.54$)$ & $(1.54)$ & $\begin{array}{c}7 \\
(10.7)\end{array}$ & $\begin{array}{c}5 \\
(7.7)\end{array}$ & $\begin{array}{l}1 \\
(1.54)\end{array}$ & $\begin{array}{c}5 \\
(11,35)\end{array}$ & $\begin{array}{l}4 \\
(9.09)\end{array}$ & $\stackrel{2}{(4.54)}$ & $\begin{array}{l}2 \\
(4.54)\end{array}$ & & $\stackrel{4}{(7.0)}$ & $\begin{array}{c}8 \\
(14)\end{array}$ & $(7.0)$ & \\
\hline & III & & & $\stackrel{8}{(12.5)}$ & $\begin{array}{c}8 \\
(12.5)\end{array}$ & $\begin{array}{l}2 \\
(3.06)\end{array}$ & $\begin{array}{l}1 \\
(2.27)\end{array}$ & $\stackrel{3}{(6.81)}$ & $\begin{array}{l}3 \\
(6.81)\end{array}$ & $\begin{array}{l}2 \\
(4.54)\end{array}$ & & $\begin{array}{l}3 \\
(5.25)\end{array}$ & $\begin{array}{c}7 \\
(12.2)\end{array}$ & $\begin{array}{c}4 \\
(7,0)\end{array}$ & \\
\hline & $大^{\mathrm{IV}}$ & $(3.06)$ & $\mid \begin{array}{l}3 \\
(4.61)\end{array}$ & $\begin{array}{c}6 \\
(9.22)\end{array}$ & $\stackrel{5}{(7.7)}$ & $\begin{array}{l}2 \\
(3.06)\end{array}$ & & $\stackrel{7}{(15.9)}$ & $\begin{array}{l}1 \\
(2.27)\end{array}$ & $\begin{array}{l}3 \\
(6.81)\end{array}$ & & $\begin{array}{l}3 \\
(5.25)\end{array}$ & $\begin{array}{c}6 \\
(10.5)\end{array}$ & $\begin{array}{c}6 \\
(10.5)\end{array}$ & \\
\hline 身 & $\mathrm{V}$ & & $(1.54)$ & $\begin{array}{l}5 \\
(7.7)\end{array}$ & $\begin{array}{c}4 \\
(6.14)\end{array}$ & & $\stackrel{2}{(4.54)}$ & & $\begin{array}{c}4 \\
(9.09)\end{array}$ & $\frac{1}{(2.27)}$ & $(2.27)$ & $(1.75)$ & $\begin{array}{c}3 \\
(5.25)\end{array}$ & $\begin{array}{c}4 \\
(7.0)\end{array}$ & $\begin{array}{l}1 \\
(1.75)\end{array}$ \\
\hline 血 & A & $\mid \begin{array}{l}1 \\
(1.54)\end{array}$ & $(1.54)$ & $\begin{array}{c}5 \\
(7.7)\end{array}$ & $\begin{array}{c}4 \\
(6.14)\end{array}$ & $\begin{array}{l}1 \\
(1.54)\end{array}$ & $\begin{array}{c}3 \\
(6.81)\end{array}$ & & $(12.27)$ & $\begin{array}{c}4 \\
(9.09)\end{array}$ & \multirow{4}{*}{$\left(\begin{array}{l}1 \\
(2.27)\end{array}\right.$} & $\stackrel{2}{(3.5)}$ & $\begin{array}{c}4 \\
(7)\end{array}$ & $\begin{array}{c}4 \\
(7.0)\end{array}$ & \multirow{5}{*}{$(3.5)$} \\
\hline \multirow{4}{*}{ 圧 } & 最 $\mathrm{B}$ & & & $\begin{array}{l}10 \\
(15.4)\end{array}$ & $\begin{array}{c}8 \\
(12.5)\end{array}$ & $(1.54)$ & $(2.27)$ & $\begin{array}{c}6 \\
(13.6)\end{array}$ & $\begin{array}{l}2 \\
(4.54)\end{array}$ & $\begin{array}{c}3 \\
(6.81)\end{array}$ & & $\begin{array}{c}4 \\
(7.0)\end{array}$ & $\begin{array}{c}8 \\
(14)\end{array}$ & $\begin{array}{l}4 \\
(7.0)\end{array}$ & \\
\hline & C & $\frac{2}{(3.06)}$ & $(1.54)$ & $\begin{array}{l}6 \\
(9.22)\end{array}$ & $\begin{array}{l}3 \\
(4.61)\end{array}$ & $\begin{array}{l}2 \\
(3.06)\end{array}$ & $\begin{array}{l}2 \\
(4.54)\end{array}$ & $\stackrel{2}{(4.54)}$ & $\begin{array}{c}1 \\
(2.27)\end{array}$ & & & $\stackrel{2}{(3.5)}$ & $\begin{array}{c}6 \\
(10.5)\end{array}$ & $\stackrel{2}{(3.5)}$ & \\
\hline & 小 $D$ & & $\begin{array}{c}3 \\
(4.61)\end{array}$ & $\begin{array}{c}5 \\
(7.7)\end{array}$ & $\begin{array}{c}7 \\
(10.7)\end{array}$ & $(1.54)$ & $\stackrel{2}{(4.54)}$ & $\begin{array}{c}6 \\
(13.6)\end{array}$ & $\begin{array}{c}4 \\
(9.09)\end{array}$ & $\begin{array}{l}3 \\
(6.81)\end{array}$ & & $\begin{array}{l}3 \\
(6.21)\end{array}$ & $\begin{array}{c}6 \\
(10.5)\end{array}$ & $\begin{array}{c}7 \\
(12.2)\end{array}$ & \\
\hline & $\mathrm{E}$ & & & $\begin{array}{c}2 \\
(3.06)\end{array}$ & $\begin{array}{l}2 \\
(3.06)\end{array}$ & & & & $\underset{(4.54)}{2}$ & & $(2.27)$ & & $\left(\begin{array}{l}1 \\
(1.75)\end{array}\right.$ & $\stackrel{2}{(3.5)}$ & \\
\hline
\end{tabular}




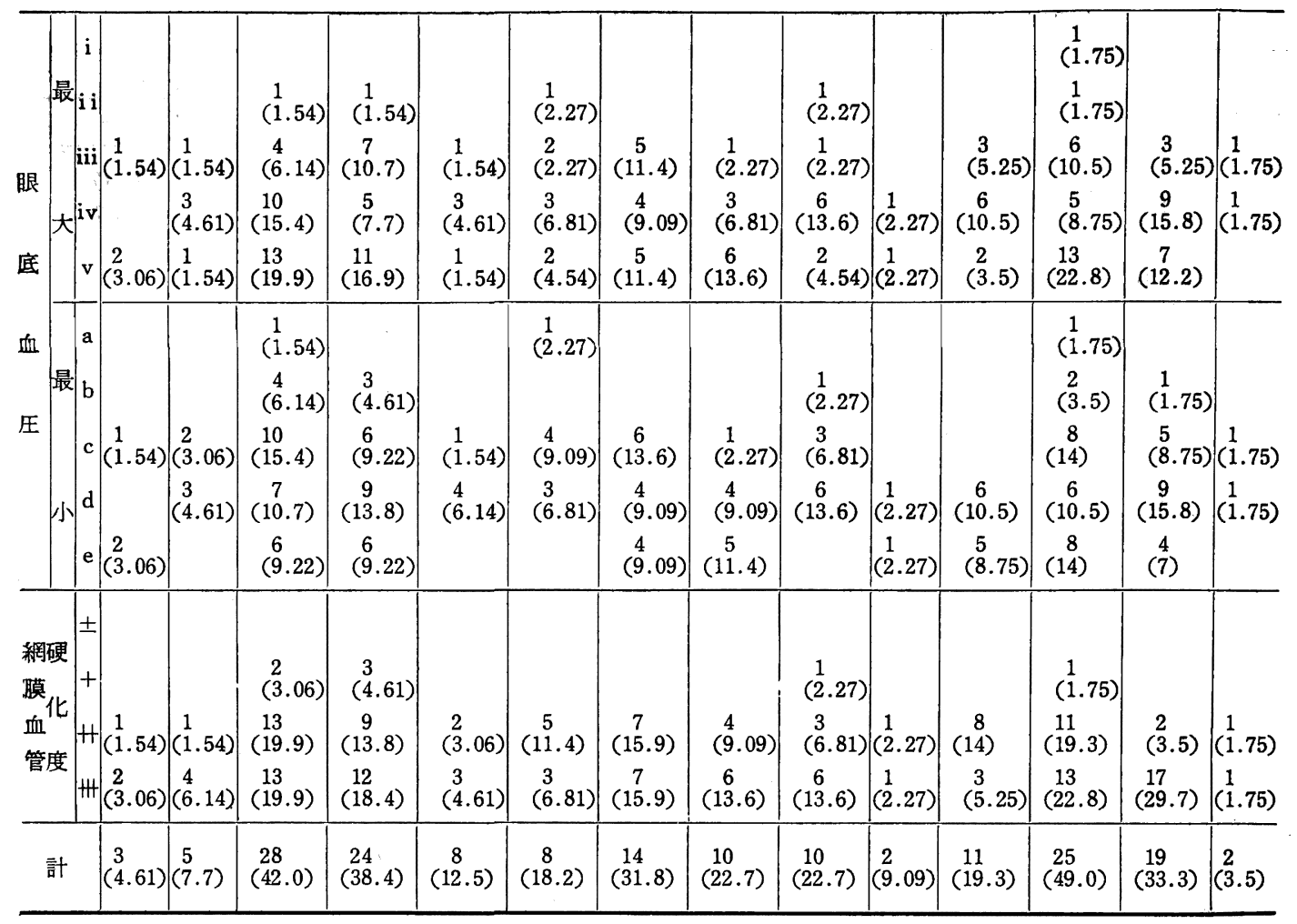

第 10 表 心疾患死亡者の

\begin{tabular}{|c|c|c|c|c|c|c|c|c|c|c|c|c|c|}
\hline & & \multicolumn{2}{|r|}{ 尿 } & 蛋 & \multicolumn{2}{|l|}{ 白 } & \multicolumn{2}{|r|}{ 細 顆 } & \multicolumn{3}{|c|}{ 粒 萎 縮 } & \multicolumn{2}{|c|}{ 老 人 } \\
\hline & & - & \pm & + & H & 册 & - & \pm & + & $H$ & \# & - & \pm \\
\hline $\begin{array}{l}\text { 基 } \\
\text { 底 } \\
\text { 動 } \\
\text { 脉 }\end{array}$ & $\begin{array}{l}+ \\
\pm \\
+ \\
+ \\
\text { H }\end{array}$ & 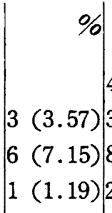 & $\begin{array}{rr} & \% \\
4 & (4.76) \\
3 & (3.57) \\
8 & (9.53) \\
2 & (2.38)\end{array}$ & $\begin{array}{c}\% \\
1(1.19) \\
10(11.9) \\
10(11.9) \\
1(1.19)\end{array}$ & $\begin{array}{r}\% \\
3(3.57) \\
9(10.7) \\
12(14.3) \\
3(3.57)\end{array}$ & $\left|\begin{array}{ll}3 & (3.57) \\
5 & (5.95)\end{array}\right|$ & $\%$ & $\begin{array}{ll} & \% \\
2 & (3.27) \\
7(11.2) \\
1 & (1.64)\end{array}$ & $\begin{array}{r}\% \\
3(4.91) \\
10(16.4) \\
21(34.4) \\
3(4.91)\end{array}$ & $\left|\begin{array}{rr|r|} & & \\
4 & (6.55) \\
4 & (6.55) & 1 \\
1 & (1.64)\end{array}\right| 1$ & $\begin{array}{lr} & \% \\
1 & (1.64) \\
1 & (1.64) \\
2 & (3.27) \\
1 & (1.64)\end{array}$ & $2(3.22)$ & $\begin{array}{ll}2 & (3.22) \\
3 & (4.84)\end{array}$ \\
\hline $\begin{array}{l}\text { 前 } \\
\text { 脳 } \\
\text { 動 } \\
\text { 脉 }\end{array}$ & $\begin{array}{l}- \\
\pm \\
+ \\
H \\
\text { H }\end{array}$ & $\begin{array}{ll}1 & (2) \\
1 & (2) \\
1 & (2)\end{array}$ & $\begin{array}{l}5(10) \\
3(6) \\
3(6)\end{array}$ & $\begin{array}{l}3(6) \\
1(2) \\
5(10) \\
1(2)\end{array}$ & $\begin{array}{l}3(6) \\
4(8) \\
9(18) \\
2(4) \\
1(2)\end{array}$ & $\begin{array}{ll}1 & (2) \\
1 & (2)\end{array}$ & & $\begin{array}{l}4(10.8) \\
2(5.4) \\
4(10.8)\end{array}$ & $\begin{array}{l}4(10.8) \\
2(5.4) \\
6(16.2) \\
4(10.8)\end{array}$ & $\mid$\begin{tabular}{ll|l}
3 & $(8.1)$ & 1 \\
2 & & \\
1 & $(2.7)$ &
\end{tabular} & $\begin{array}{ll}1 & (2.7) \\
2 & (5.4) \\
2 & (5.4)\end{array}$ & $\left|\begin{array}{ll}1 & (2.27) \\
1 & (2.27)\end{array}\right|$ & $\begin{array}{ll}1 & (2.27) \\
3 & (6.82) \\
1 & (2.27)\end{array}$ \\
\hline $\begin{array}{l}\text { 中 } \\
\text { 脳 } \\
\text { 動 } \\
\text { 脉 }\end{array}$ & $\begin{array}{l}- \\
\pm \\
+ \\
H \\
\text { H }\end{array}$ & $\left|\begin{array}{ll}1 & (2.27) \\
2 & (4.55) \\
1 & (2.27)\end{array}\right|$ & $\begin{array}{ll}3 & (6.82) \\
3 & (6.82) \\
4 & (9.1)\end{array}$ & $\begin{array}{ll}2 & (4.55) \\
2 & (4.55) \\
6 & (13.6)\end{array}$ & $\begin{array}{l}1(2.27) \\
6(13.6) \\
7(15.7) \\
4(9.1)\end{array}$ & $\left|\begin{array}{ll}1 & \\
1 & (2.27) \\
1 & (2.27)\end{array}\right|$ & & $\begin{array}{ll}1 & (2.86) \\
2 & (5.72) \\
3 & (8.58) \\
4 & (11.4)\end{array}$ & $\begin{array}{l}1(2.86) \\
5(14.3) \\
5(14.3) \\
5(14.3)\end{array}$ & $\left|\begin{array}{ll}1 & (2.86) \\
3 & (8.58) \\
1 & (2.86)\end{array}\right| 2$ & $\begin{array}{ll}2 & (5.72) \\
2 & (5.72)\end{array}$ & $1 \begin{array}{ll}1 & (2.5) \\
1 & (2.5)\end{array}$ & $\begin{array}{ll}1 & (2.5) \\
1 & (2.5) \\
2 & (5) \\
1 & (2.5)\end{array}$ \\
\hline $\begin{array}{l}\text { 後 } \\
\text { 脳 } \\
\text { 動 } \\
\text { 脉 }\end{array}$ & $\begin{array}{l}- \\
\pm \\
+ \\
H \\
\text { H }\end{array}$ & $\mid \begin{array}{ll}1 & (2.32) \\
1 & (2.32) \\
1 & (2.32)\end{array}$ & $\begin{array}{ll}1 & (2.32) \\
1 & (2.32) \\
7 & (16.4) \\
2 & (4.64)\end{array}$ & $\begin{array}{ll}1 & (2.32) \\
1 & (2.32) \\
3 & (6.98) \\
4 & (9.3)\end{array}$ & $\begin{array}{l}2(4.64) \\
1(2.32) \\
9(20.9) \\
7(16.4)\end{array}$ & $|1(2.32)|$ & & $\begin{array}{ll}2 & (6.06) \\
2 & (6.06) \\
1 & (3.03) \\
2 & (6.06)\end{array}$ & $\begin{array}{c}1(3.03) \\
1(3.03) \\
10(30.3) \\
5(15.2)\end{array}$ & $\left|\begin{array}{ll}1 \\
1 & (3.03) \\
3 & (9.09)\end{array}\right| 2$ & $\begin{array}{ll}1 & (3.03) \\
2 & (6.06) \\
2 & (6.06)\end{array}$ & $\left|\begin{array}{ll}1 & (2.44) \\
1 & (2.44)\end{array}\right|$ & $\mid \begin{array}{ll}1 & (2.44) \\
1 & (2.44) \\
2 & (4.88) \\
1 & (2.44)\end{array}$ \\
\hline
\end{tabular}


化の程度の間にも特に相関的関保を認め得ない。然し 薚動脈硬化度の強い程の者では網膜血管の硬化も可な り強い者が極めて多い。

d）剖検時の脳血管所見 と 留所見との関係 （第10 表)。

直接死因が心疾患であつた者の脳血管剖検所見と腎 剖検所見其の他を比較するに，尿蛋白量の增加するに つれ，又腎動脈硬化度が増強するてつれ，脳血管中殊 飞基底，中脳及び後脳動脈の硬化度が漸次例数的飞增 加する傾向が見られるが，前脳動脈硬化度にあつては かかる傾向はみられない。

細顆粒萎縮と脳動脈では，中脳動脈の硬化度とこの 萎縮の間には明白に萎縮の増強と俱に中脳動脈硬化の 強い者のみである事を認めている。

老人性腎萎縮と脳血管硬化度, 真性の良性萎縮腎と 脳血管硬化度との間には表飞るる如く，脳血管硬化度 と萎縮の間には関係ある如き所見は全く認められてい ない。

5）直接死因が脳疾㭧即ち出血或いは軟化にありと された者の臨床的並びそ剖検的統計成績。

a）我々が剖検を行つた症例 308 例中，特飞脳疾患 死亡者のみに限局せす，心電図を撮影した症例は表の
如く 177 例がある。177 例中心電図化異常を認めなか つた者は 74 例 (41.9\%) で残り 103 例は心電図学的 飞表の如き診断が生存中につけられた。即ち心筋傷害 のみありとされた者は 55 例 (31.8\%) で圧倒的飞多 く，之に次ぐのが心筋傷害に左心室肥大を合併した者 12例 (6.71\%)，次いで心筋梗塞の 8 例，脚ブロック 8 例 (4.47\%) が之に次いでいる。心筋傷害を有する すのは実に 77 例 (38.1\%) の多きに達するわけであ り, 左心室肥大は 19 例 $(9.38 \%)$ を算することに なる (第 3 表参照)。同一人で各種の心障害を有する 結果になつた者が 23 例もある事は注目に值する。然 し高年者になつても全く異常のない者が $40 \%$ 以上も ある事は興味ある事実である。(第 11 表)

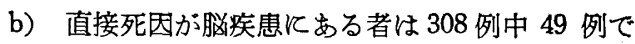
ある。之等の者の中で実際に各種検査を行つた。

i ） 38 例の心電図所見 と全身眼底両血圧及び網膜 血管硬化度との関係（第 12 表）をみると，心電図に 異常のある者, 無い者いづれに於ても皆網膜血管硬化 度は圧倒的に中等度以上が大部分（38 例中 37 例）て あり，眼底血圧は最大最小とも悉く $\mathrm{iii} ， \mathrm{C}$ 型以上で 高い者許りである。全身血圧も高い者が相当数汇認め られ, 最大血圧は悉く而型以上, 最小血圧は 38 例中

脳血管と腎所見との関係

\begin{tabular}{|c|c|c|c|c|c|c|c|c|c|c|c|c|}
\hline 性 & 縮 & & & 良 性 & 真 性 萎 & 萎 縮 腎 & & & 動 & 脉 & 化 & \\
\hline+ & $H$ & H & - & \pm & + & $H$ & W & - & \pm & + & $H$ & WI \\
\hline $\begin{array}{l}\% \\
2(3.22) \\
9(14.5) \\
13(21) \\
2(3.22)\end{array}$ & $\begin{array}{r}\% \\
2(3.22) \\
8(12.9) \\
11(17.7) \\
4(6.45)\end{array}$ & $6\left|\begin{array}{rr} & \% \\
1 & (1.61) \\
1 & (1.61) \\
2 & (3.22)\end{array}\right|$ & $\begin{array}{r}\% \\
3(8.58) \\
\end{array}$ & $\left|\begin{array}{r}\% \\
2(5.72) \\
4(11.4) \\
2(5.72)\end{array}\right|$ & $\left\{\begin{array}{r}\% \\
1(2.86) \\
6(17.2) \\
4(11.4)\end{array}\right.$ & $\begin{array}{r}\% \\
4(11.4) \\
8(22.8)\end{array}$ & $\mid \begin{array}{rr} & \% \\
1 & (2.86) \\
2 & (5.72)\end{array}$ & $\%$ & $\begin{array}{r}\% \\
3(6.98) \\
6(13.8)\end{array}$ & $\begin{array}{r}\% \\
5(11.6) \\
6(13.8) \\
7(16.4)\end{array}$ & $\begin{array}{c}2(4.64) \\
13(30.2)\end{array}$ & \\
\hline $\begin{array}{l}5(11.4) \\
1(2.27) \\
5(11.4) \\
2(4.55)\end{array}$ & $\begin{array}{l}3(6.82) \\
4(9.1) \\
6(13.6) \\
3(6.82) \\
1(2.27)\end{array}$ & $\mid \begin{array}{ll}1 & (2.27) \\
2 & (4.55) \\
2 & (4.55)\end{array}$ & 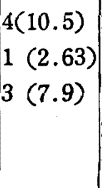 & $\left|\begin{array}{ll}2 & (5.26) \\
1 & (2.63) \\
7 & (18.4) \\
2 & (5.26)\end{array}\right|$ & $\left|\begin{array}{ll}1 & (2.63) \\
2 & (5.26) \\
4 & (10.5) \\
2 & (5.26)\end{array}\right|$ & $\left|\begin{array}{ll}1 & (2.63) \\
1 & (2.63) \\
2 & (5.26) \\
3 & (7.9) \\
1 & (2.63)\end{array}\right|$ & $1(2.63)$ & $2(4.64)$ & $\left|\begin{array}{ll}6 & 13.8) \\
2 & (4.64) \\
3 & (6.98) \\
1 & (2.32)\end{array}\right|$ & $\begin{array}{l}4(9.3) \\
2(4.64) \\
6(13.8) \\
3(6.98)\end{array}$ & $\begin{array}{l}1(2.32) \\
2(4.64) \\
5(11.6) \\
4(9.3) \\
1(2.32)\end{array}$ & $1(2.32)$ \\
\hline $\begin{array}{l}1(2.5) \\
3(7.5) \\
3(7.5) \\
4(10)\end{array}$ & $\begin{array}{l}4(10) \\
9(22.5) \\
4(10)\end{array}$ & $\left|\begin{array}{ll}1 & (2.5) \\
1 & (2.5) \\
3 & (7.5)\end{array}\right|$ & $\begin{array}{l}1 \\
1 \\
5(2.27) \\
2(11.4) \\
2(4.55)\end{array}$ & $\left|\begin{array}{ll}1 & (2.27) \\
1 & (2.27) \\
3 & (6.82) \\
7 & (15.7) \\
2 & (4.55)\end{array}\right|$ & 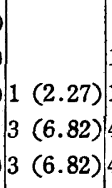 & $\mid \begin{array}{ll}1 & (2.27) \\
1 & (2.27) \\
4 & (9.1) \\
4 & (9.1)\end{array}$ & $1(2.27)$ & $1(2.44)$ & $\mid \begin{array}{ll}2 & (4.88) \\
1 & (2.44) \\
6 & (14.6) \\
1 & (2.44)\end{array}$ & $\begin{array}{l}1(2.44) \\
5(12.2) \\
8(19.5) \\
2(4.88)\end{array}$ & $\begin{array}{l}1(2.44) \\
5(12.2) \\
6(14.6)\end{array}$ & $2(4.88)$ \\
\hline $\begin{array}{l}3(7.31) \\
2(4.88) \\
4(9.76) \\
3(7.31)\end{array}$ & $\begin{array}{r}10(24.4) \\
7(12.3)\end{array}$ & $\left|\begin{array}{ll}3 & (7.31) \\
1 & (2.77)\end{array}\right|$ & $\begin{array}{ll}1 & (2.77) \\
1 & (2.77) \\
5 & (13.9) \\
1 & (2.44)\end{array}$ & $\begin{array}{l}2(5.54) \\
2(5.54) \\
4(11.1) \\
5(13.9)\end{array}$ & $\begin{array}{ll}3 & (8.34) \\
3 & (8.34)\end{array}$ & $\left|\begin{array}{ll}1 & (2.77) \\
5 & (13.9) \\
2 & (5.54)\end{array}\right|$ & $1(2.77)$ & $1(2.44)$ & $\left|\begin{array}{ll}2 & (4.88) \\
2 & (4.88) \\
6 & (14.6) \\
2 & (4.88)\end{array}\right|$ & $\begin{array}{l}3(7.31) \\
1(2.44) \\
6(14.6) \\
4(9.76)\end{array}$ & $\begin{array}{l}1(2.44) \\
6(14.6) \\
6(14.6)\end{array}$ & $1(2.44)$ \\
\hline
\end{tabular}


$-244-(1114)$

第 11 表 心電図による心変化症例数

\begin{tabular}{|c|c|c|}
\hline 心筋甥害 & 55 & $(31.80)^{\%}$ \\
\hline 左心室肥大 & 6 & $(3.36)$ \\
\hline 心觔梗塞 & 8 & $(4.47)$ \\
\hline 脚ブロック & 8 & $(4.47)$ \\
\hline 洞性速脉 & 3 & $(1.68)$ \\
\hline 心筋甥害＋心筋梗塞 & 3 & $(1.68)$ \\
\hline 心筋傷害+左心室肥大 & 12 & $(6.71)$ \\
\hline 心筋傷害+脚ブロック & 4 & $(2.23)$ \\
\hline 心笳傷害＋心筋梗塞＋洞性速脉 & 1 & $(0.56)$ \\
\hline 心笳傷害十洞性速脉 & 1 & $(0.56)$ \\
\hline 心筋傷害＋左心室肥大+洞性速脉 & 1 & $(0.56)$ \\
\hline 心箊梗塞＋洞性速脉 & 1 & $(0.56)$ \\
\hline 異常なし & 74 & $(41.90)$ \\
\hline 計 & 177 & $(100.00)$ \\
\hline
\end{tabular}

35 例がC型以上であつた。

ii ）脳疾患による死亡者の全身眼底血圧, 網膜血管 硬化度と剖検による冠動脈硬化との関係（第 13 表）

脳卒中死亡者にあつては冠動脈の硬化が認められぬ 者は僅か、2 例で極めて少い。而して冠動脈の硬化 (軽度及び中等度)のある者に於ては眼底血圧及び全身
血圧はいつれも高い者が大多数であり, 又眼底所見す 殆んど悉くは中等度硬化以上であるが, 冠動脈の硬化 自体には高度の硬化と称せられる者は 1例もない。冠 動脈の狭窄は認められぬ者の方が軽度狭窄の者より粪 かに多く, 冠動脈の閉塞は 1 例も認められなかつた。

iii）全身眼底両血圧, 網膜血管硬化度と左心室変化 との関係（第 14 表）

左心室の肥大は血圧が全身眼底俱に可なり高く而も 網膜血管硬化が中等度以上の者です肥大の全く認めら れぬ者が 5 例 (11.6\%) にみられてはいるが, 全般的 にみて肥大が軽度 (17 例) 中等度 (16 例) の者が最 も多く（両者で 76\%以上）, 高度の肥大は僅か、 1 例 のみである。

左心室の拡張の全くみられぬ者 13 例 (30.2\%), 軽 度拡張 15 例 (34.996) 微度拡張 8 例, 中等度拡張は 6 例 (13.9\%) であるが，網膜血管硬化度は殆んど大 部分が中等度硬化以上の者であり, 眼底血圧は拡張の 有無に拘らず悉く $\mathrm{iii}, \mathrm{C}$ 型以上の者のみであり, 全身 血圧は拡張のない者の少数だけ軽度の高血圧がみられ

第 12 表 直接死因が脳血管傷害によるものの心電図所見と血圧及び眼底所見との関係

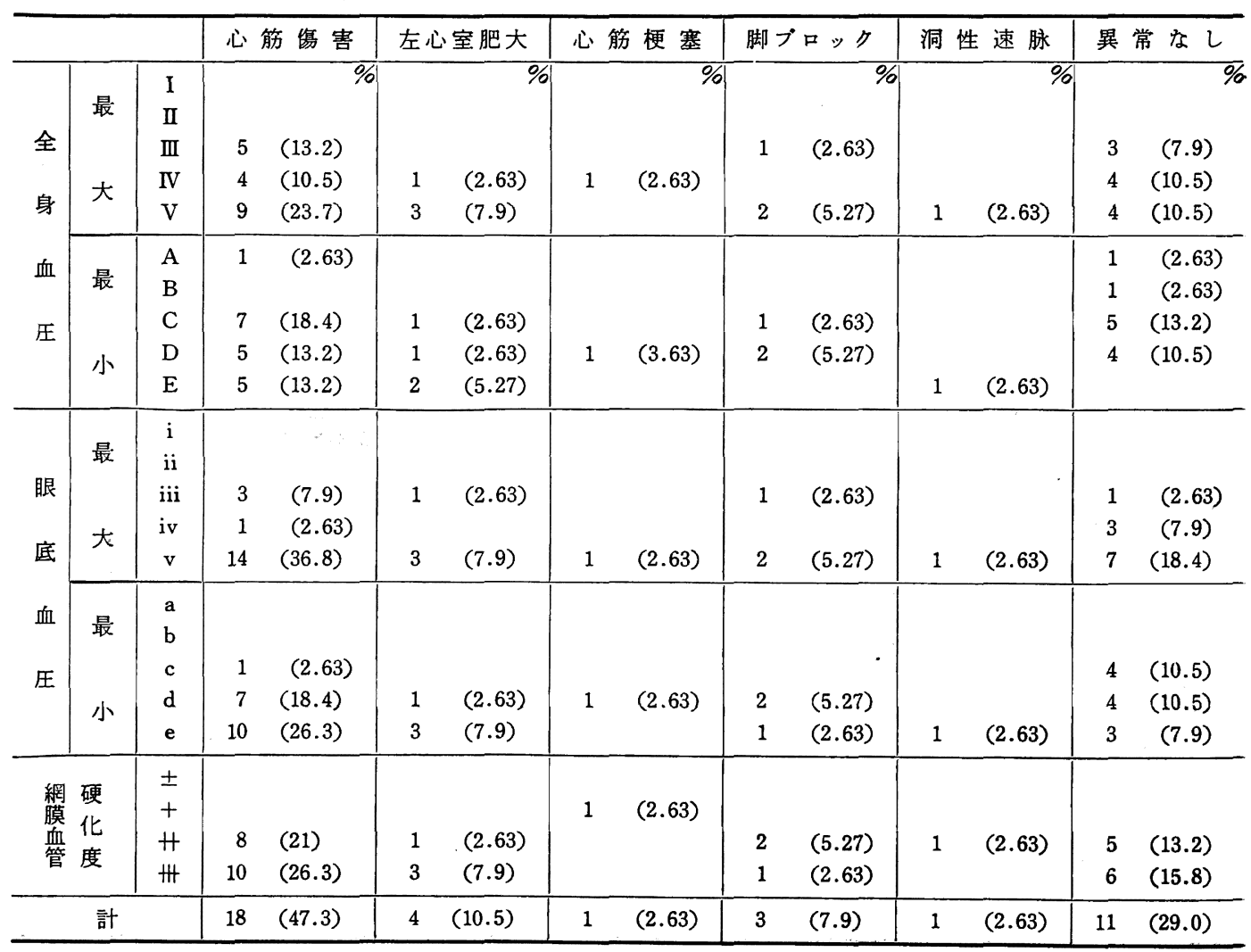


第 13 表 直接死因が脳疾患によるものの冠動脉変化と血在及び眼底所見との関釈

\begin{tabular}{|c|c|c|c|c|c|c|c|c|c|c|c|c|}
\hline & \multicolumn{2}{|c|}{ 硬 } & \multicolumn{2}{|l|}{ 化 } & \multicolumn{2}{|c|}{ 狭 } & \multicolumn{2}{|l|}{ 窄 } & \multirow{2}{*}{ 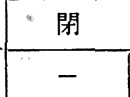 } & \multirow{2}{*}{$\frac{\text { 塞 }}{+}$} \\
\hline & & & - & + & $H$ & 世 & - & + & $H$ & W & & \\
\hline 身 & 最 & $\begin{array}{l}\text { I } \\
\text { II } \\
\text { III } \\
\text { IV } \\
\text { V }\end{array}$ & 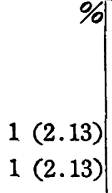 & $\begin{array}{r}\% \\
5(10.6) \\
10(21.3) \\
11(23.4)\end{array}$ & $\begin{array}{l}3(6.4) \\
8(17) \\
8(17)\end{array}$ & & $\begin{array}{l}\% \\
1(4.55) \\
5(22.6) \\
7(31.8)\end{array}$ & $\begin{array}{l}3(13.6) \\
3(13.6) \\
2(9.1)\end{array}$ & \pm & & $\begin{array}{lr} & \\
5 & (22.6) \\
8 & (36.4) \\
9 & (40.9)\end{array}$ & \\
\hline 血 & 最 & $\begin{array}{l}\text { A } \\
\text { B } \\
\text { C } \\
\text { D } \\
\text { E }\end{array}$ & $\begin{array}{l}1(2.13) \\
1(2.13)\end{array}$ & $\begin{array}{c}3(6.4) \\
1(2.13) \\
8(17) \\
10(21.3) \\
5(10.6)\end{array}$ & $\begin{array}{l}2(4.26) \\
6(12.8) \\
6(12.8) \\
5(10.6)\end{array}$ & & $\begin{array}{l}1(4.55) \\
6(27.2) \\
4(18.2) \\
2(9.1)\end{array}$ & 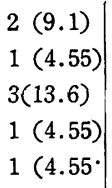 & $1(4.55)$ & & $\begin{array}{rr}2 & (9.1) \\
2 & (9.1) \\
10 & (45.5) \\
5 & (22.6) \\
3 & (13.6)\end{array}$ & \\
\hline 底 & 最 & $\begin{array}{l}\text { i } \\
\text { ii } \\
\text { iii } \\
\text { iv } \\
\text { v }\end{array}$ & $\begin{array}{l}1(2.13) \\
1(2.13)\end{array}$ & $\begin{array}{c}4(8.52) \\
9(19.2) \\
13(27.7)\end{array}$ & $\begin{array}{c}1(2.13) \\
4(8.52) \\
14(29.8)\end{array}$ & & $\begin{array}{l}2(9.1) \\
11(50)\end{array}$ & $\begin{array}{ll}1 & (4.55) \\
2 & (9.1) \\
5 & (22.6)\end{array}$ & $1(4.55)$ & & $\begin{array}{rr}3 & (13.6) \\
2 & (9.1) \\
17 & (77.3)\end{array}$ & \\
\hline 圧 & 小 & $\begin{array}{l}a \\
b \\
c \\
d \\
\text { e }\end{array}$ & & $\begin{array}{r}6(12.8) \\
7(14.9) \\
13(27.7)\end{array}$ & $\begin{array}{l}5(10.6) \\
7(14.9) \\
7(14.9)\end{array}$ & & $\begin{array}{l}1(4.55) \\
7(31.8) \\
5(22.6)\end{array}$ & $\begin{array}{l}3(13.6) \\
1(4.55) \\
7(18.2)\end{array}$ & $1(4.55)$ & & $\begin{array}{l}4(18.2) \\
9(40.9) \\
9(40.9)\end{array}$ & \\
\hline 舟 & & $\begin{array}{l} \pm \\
+ \\
H \\
\text { H }\end{array}$ & $\begin{array}{l}1(2.13) \\
1(2.13)\end{array}$ & $\begin{array}{c}1(2.13) \\
9(19.2) \\
16(34.1)\end{array}$ & $\begin{array}{r}6(12.8) \\
13(27.7)\end{array}$ & & $\begin{array}{r}3(13.6) \\
10(45.5)\end{array}$ & $\begin{array}{l}1(4.55) \\
4(18.2) \\
3(13.6)\end{array}$ & $1(4.55)$ & & $\mid \begin{array}{cc}1 & (4.55) \\
8 & (36.4) \\
13 & (59.1)\end{array}$ & \\
\hline & 計 & & $2(4.26)$ & $26(55.2)$ & $19(40.4)$ & 0 & $13(59)$ & $8(36.3)$ & $1(4.55)$ & 0 & $22(100)$ & 0 \\
\hline
\end{tabular}

第 14 表 直接死因が脳疾患によるものの左心室变化と血圧及び眼底所見との関係

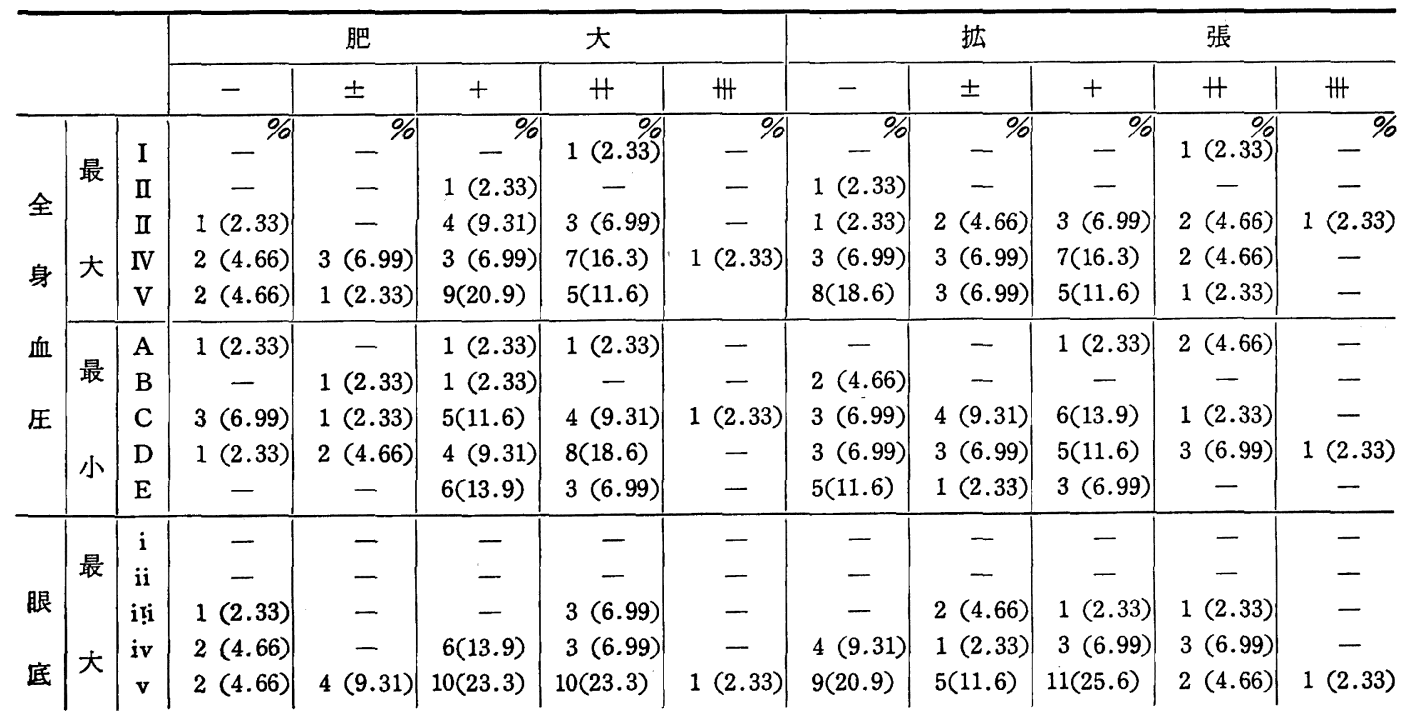




\begin{tabular}{l} 
血最 \\
\cline { 3 - 5 }
\end{tabular}

第 15 表 直接死因が脳疾患によるものの心筋の変化と血圧および脸底所見との関係

\begin{tabular}{|c|c|c|c|c|c|c|c|c|c|c|c|c|c|c|}
\hline & \multicolumn{4}{|c|}{ 混 } & \multicolumn{2}{|l|}{ 胼 } & \multicolumn{2}{|c|}{ 壊 死 } & \multicolumn{2}{|c|}{ 梗 } & \multicolumn{2}{|c|}{ 塞 } \\
\hline & & & - & +1 & H & m & - & + & H & 册 & - & + & $H$ & m \\
\hline \multirow{4}{*}{ 全 } & & I & $-\%$ & $-\%$ & $-\%$ & $-\%$ & $-\%$ & $-\%$ & $-\%$ & $-\%$ & $-\%$ & $-\%$ & $-\%$ & $-\%$ \\
\hline & 最 & II & - & - & - & - & - & - & - & - & - & - & - & - \\
\hline & & III & $2(12)$ & $3(12)$ & $1(9)$ & - & $3(12)$ & $3(12)$ & - & - & $6(24)$ & - & - & - \\
\hline & 大 & IV & - & $3(12)$ & $5(20)$ & $1(4)$ & $3(12)$ & $5(20)$ & $1(4)$ & - & $8(32)$ & 1 (4) & - & - \\
\hline 身 & & V & $1(4)$ & $8(32)$ & $1(4)$ & - & $7(28)$ & $3(12)$ & - & - & $9(36)$ & $1(4)$ & - & - \\
\hline \multirow{5}{*}{ 血 } & 是 & A & $1(4)$ & $1(4)$ & - & - & $2(8)$ & - & - & - & $2(8)$ & - & - & - \\
\hline & 取 & B & - & $2(8)$ & - & - & - & $1(4)$ & $1(4)$ & - & $2(8)$ & - & - & - \\
\hline & & C & $1(4)$ & $6(24)$ & $4(16)$ & - & $5(20)$ & $6(24)$ & - & - & $11(44)$ & - & - & - \\
\hline & 小 & D & $1(4)$ & $3(12)$ & $2(8)$ & $1(4)$ & $4(16)$ & $3(12)$ & - & - & $5(20)$ & $2(8)$ & - & - \\
\hline & & $\mathrm{E}$ & - & $2(8)$ & $1(4)$ & - & $2(8)$ & $1(4)$ & - & - & $3(12)$ & - & - & - \\
\hline \multirow{4}{*}{ 眼 } & 量 & $\mathrm{i}$ & - & - & - & - & - & - & - & - & - & - & - & - \\
\hline & 取 & ii & - & - & - & - & - & - & - & - & - & $T$ & - & - \\
\hline & & iii & - & $2(8)$ & $1(4)$ & - & $1(4)$ & $2(8)$ & - & - & $3(12)$ & - & - & - \\
\hline & 大 & iv & $2(8)$ & - & $1(4)$ & - & $3(12)$ & - & - & - & $3(12)$ & - & - & - \\
\hline 底 & & $\mathrm{v}$ & $1(4)$ & $12(48)$ & $5(20)$ & 1 (4) & $9(36)$ & $9(36)$ & $1(4)$ & - & $17(68)$ & $2(8)$ & - & - \\
\hline \multirow{2}{*}{ 血 } & 昌 & a & - & - & - & - & - & - & - & - & - & - & - & - \\
\hline & 取 & b & - & - & - & - & - & - & - & - & - & - & - & - \\
\hline \multirow[t]{3}{*}{ 圧 } & & c & $1(4)$ & $3(12)$ & - & - & $2(8)$ & $1(4)$ & $1(4)$ & - & $4(16)$ & - & - & - \\
\hline & 小 & d & - & $5(20)$ & $4(16)$ & - & $4(16)$ & $5(20)$ & - & - & $7(28)$ & $2(8)$ & - & - \\
\hline & & e & $2(8)$ & $6(24)$ & $3(12)$ & $1(4)$ & $7(28)$ & $5(20)$ & - & - & $12(48)$ & - & - & - \\
\hline \multirow{4}{*}{$\begin{array}{l}\text { 網砳 } \\
\text { 膜 } \\
\text { 血 } \\
\text { 管目 }\end{array}$} & & \pm & - & - & - & - & - & - & - & - & - & - & - & - \\
\hline & & + & - & - & 1 (4) & - & - & 1 (4) & - & - & 1 (4) & - & - & - \\
\hline & & $H$ & $3(12)$ & $6(24)$ & 1 (4) & - & $5(20)$ & $5(20)$ & - & - & $9(36)$ & 1 (4) & - & - \\
\hline & & W & & $8(32)$ & $5(20)$ & $1(4)$ & $8(32)$ & $5(20)$ & $1(4)$ & - & $13(52)$ & $1(4)$ & - & - \\
\hline \multicolumn{3}{|c|}{ 計 } & $3(12)$ & $14(56)$ & $7(28)$ & $1(4)$ & $13(52)$ & $11(44)$ & $1(4)$ & 0 & 23(92) & $2(8)$ & 0 & 0 \\
\hline
\end{tabular}

たのみで, 多くは矢張り III C 型以上の者で占められて いる㑯向が翀められる。

iv ）全身眼底両血圧, 網膜血管硬化度と心筋の変化 との関係 (第 15 表)。

剖検時に於ける心筋の変化としてはその混濁の程 度, 胼脤壊死の具合, 梗塞の状態を検討した。

心筋の混濁の全く認められないのに網膜血管硬化中 等度の者が 3 例, 又眼底血圧の比較的高い者も 3 例あ
つたが，全般的にみて軽度の混濁が最も多く 14 例 （56.0\%）を占め，中等度混濁は 7 例 $(28.0 \%)$ であ り, 混濁が徐々に増加するにつれ, 全身血圧, 眼底血 圧の高い者が増加していく傾向を認めるし，網膜血管 硬化も割合に強い者が多い。

胼胝壊死の全く認められぬ者は25例中13例 (52\%)， 之を有する者 12 例 (48\%) でほほ両者は相半ばし， 而も 12 例の程度もごく軽度の胼胝であり噮死であつ 
第 16 表 直接死因が脸血管傷害にあるすのの尿蛋白と血圧及び脸底所見との関係

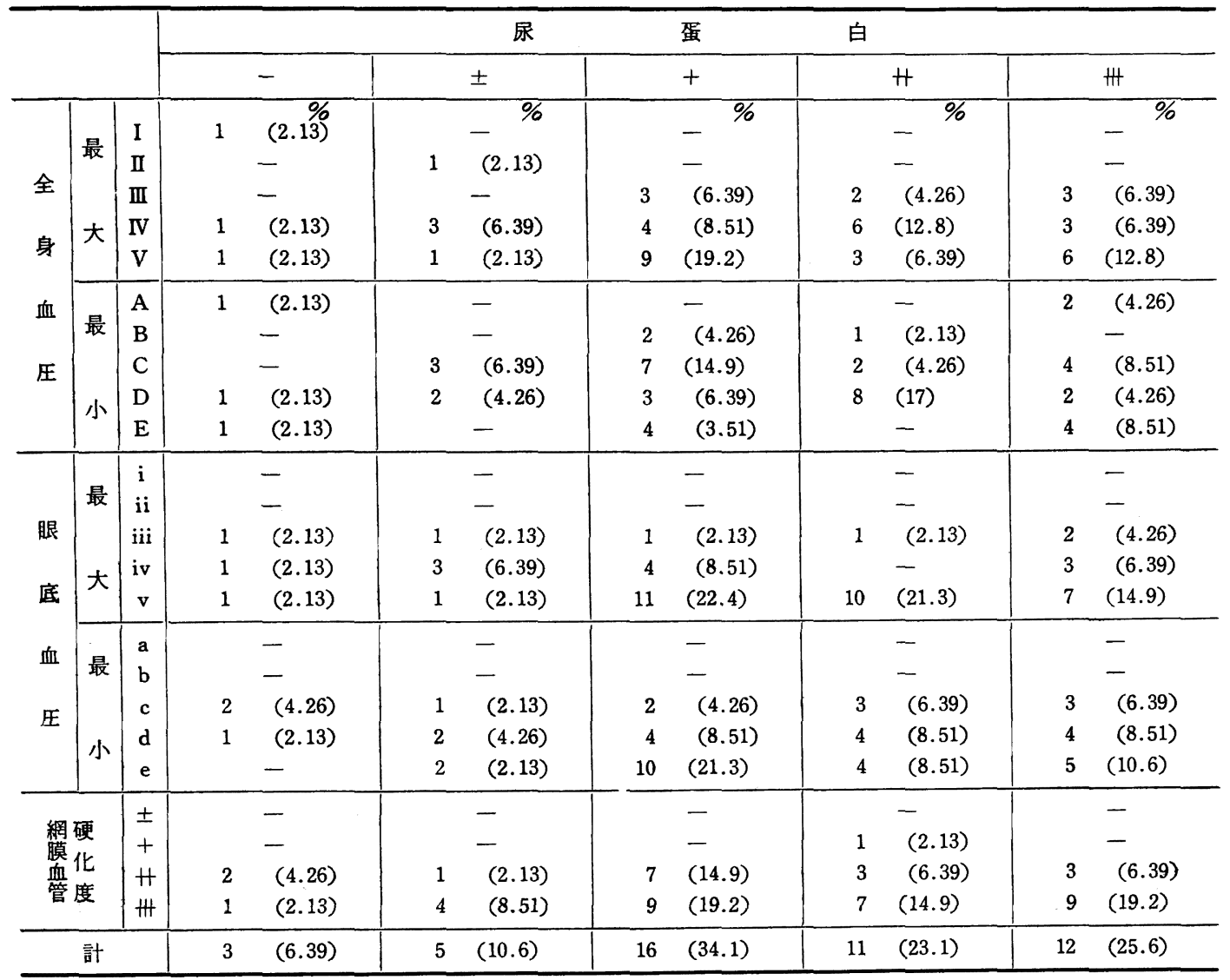

た。

梗塞は之を全く認めぬ者は 25 例中 23 例 (92\%) 認めた者は軽度の梗塞のみ僅かに2例 (8.0\%) で大 部分の眼底血圧は比較的高いが, 網膜血管の硬化は 23 例中 22 例迄は中等度硬化以上の者であつた。

c）全身眼底両血圧，網膜血管硬化度と腎所見との 関係に就いて。

i ）血圧, 網膜血管硬化度と尿蛋白との関係

(第 16 表)。

脳疾患死亡者例中の尿蛋白は陰性者は僅かに 3 例で 他は悉く陽性者である。尚蛋白陽性度が増加するにつ れてその症例数も増加し，而も殆んど大多数が眼底血 管の硬化度は中等度陽性者許りであつて（44 例中 43 (列), 蛋白陽性度の増加と眼底血管硬化度の強い者の 数が割合に平行的に増加している傾向がみとめられ る。一方眼底血圧は悉く $\mathrm{iiC}$ 型以上の者許りで, 而 も最大血圧は蛋白陽性度の高い者が増すにつれ可なり 増加しているが最小血圧ではかかる傾向はみられな
い。又全身血圧でも最大血圧は蛋白陽性度が増加する につれ高い血圧の者許りになつているが，最小血圧で はかかる傾向は認められていない。

ii ）血圧, 網膜血管硬化度と腎剖検所見との関係 (第 17,18 表)。

肉眼的腎剖検結果中細顆粒萎縮では萎縮軽度のもの が最も多く之等の眼底血圧は iiiC 型が最も多く総て が之に含まれるが，全身最大血圧です亚型が悉くで， 総数中の大多数がここに含まれる。然し督萎縮最高度 のものは僅か江 1 例のみである。網膜血管硬化度は矢 張り萎縮軽度のものが最多数且つ大部分は中等度硬化 以上で高度硬化は 34 例中 17 例で，細顆粒萎縮のある ものは 34 例中 22 例が高度の網膜血管硬化像を示めし ている。従つて細顆粒萎縮と血圧の間に特に関係ある とは考元られぬが, 網膜血管硬化度の強い者の中には 細顆粒萎縮が悉く含まれていることから，細顆粒巷縮 が認められる場合には眼底血管硬化度は必らず存在す ると思つて先つ間違いなさそうである。粗大顆粒萎縮 
第 17 表 直接死因が脳血管傷害にあるものの腎剖検所見と血圧及び眼底所見との関俰

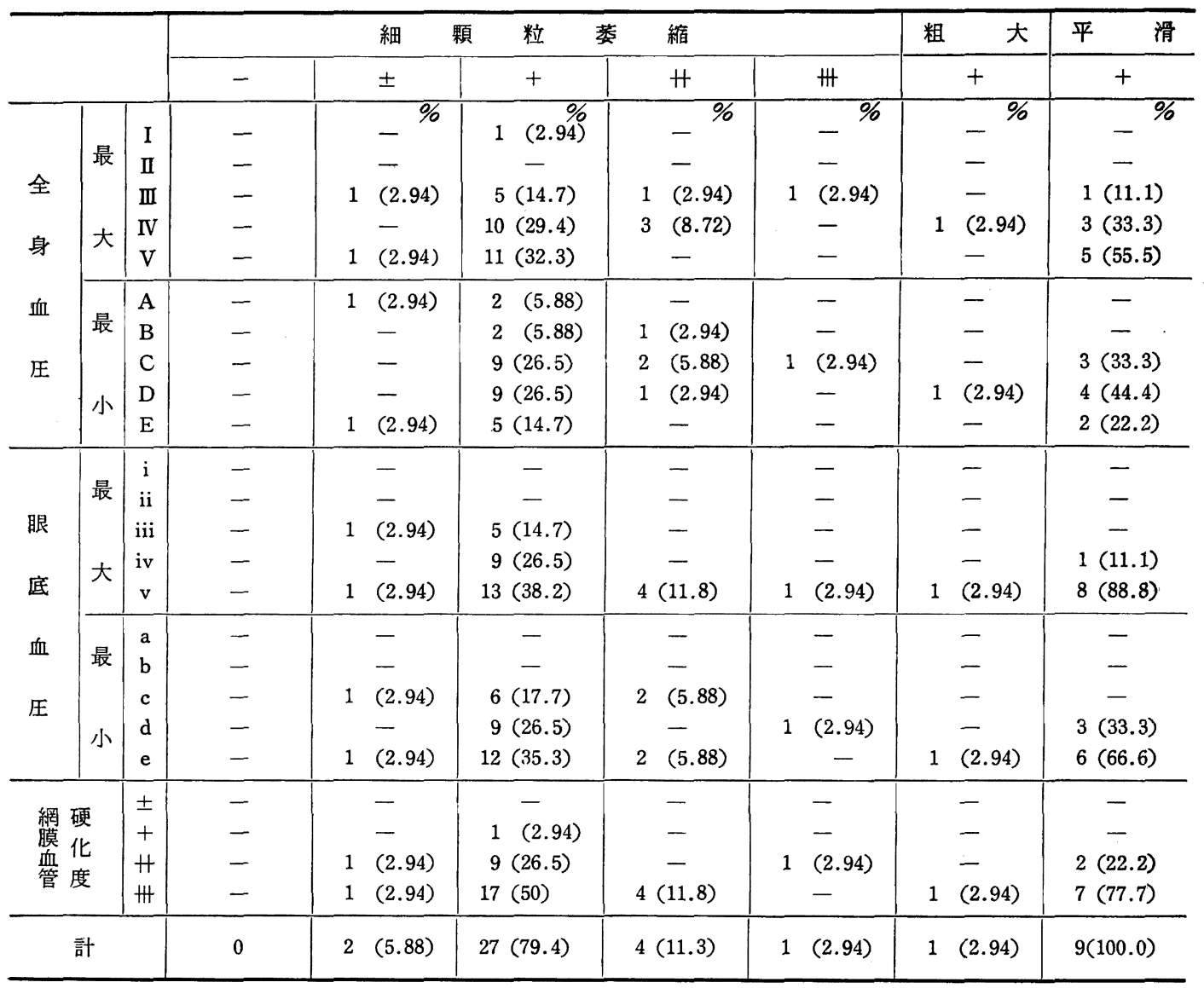

第 18 表 直接死因が脳血管傷害にあるものの腎剖検見と血圧及び眼底所見との関係

\begin{tabular}{|c|c|c|c|c|c|c|c|c|c|c|c|c|c|c|c|}
\hline & \multicolumn{4}{|r|}{ 縮 } & \multicolumn{5}{|c|}{ 良性 真 性 萎 腎 } & \multicolumn{4}{|c|}{ 動 脉 硬 化 } \\
\hline & & & - & \pm & + & \# & - & \pm & + & H & H & \pm & + & H & m \\
\hline \multirow{4}{*}{ 全 } & & I & $-\%$ & $-\%$ & $-\%$ & $-\%$ & $-\%$ & $-\%$ & $-\%$ & $-\%$ & $-\%$ & -\% & $-\%$ & -\% & $\%$ \\
\hline & 最 & II & - & - & - & - & - & - & - & - & - & _ & $1(4)$ & - & - \\
\hline & & III & - & - & $3(11.1)$ & $3(11.1)$ & $2(8.32)$ & $2(8.32)$ & - & - & $1(4.16)$ & - & $3(12)$ & $2(8)$ & - \\
\hline & 大 & IV & - & - & $4(14.8)$ & $5(18.5)$ & $2(8.32)$ & $2(8.32)$ & $4(16.7)$ & $1(4.16)$ & - & $1(4)$ & $4(16)$ & $4(16)$ & - \\
\hline 身 & & $\mathrm{V}$ & $1(3.7)$ & $1(3.7)$ & $5(18.5)$ & $5(18.5)$ & $4(16.7)$ & $4(16.7)$ & $2(8.32)$ & - & - & $4(16)$ & $1(4)$ & $3(12)$ & - \\
\hline \multirow{5}{*}{ 圧 } & & A & - & - & $1(3.7)$ & $1(3.7)$ & $1(4.16)$ & $1(4.16)$ & - & - & - & - & $1(4)$ & $1(4)$ & - \\
\hline & 最 & B & - & - & - & $2(7.4)$ & - & - & $2(8.32)$ & - & - & - & $1(4)$ & $1(4)$ & - \\
\hline & & $\mathrm{C}$ & $1(3.7)$ & - & $3(11.1)$ & $7(26)$ & $4(16.7)$ & $3(12.5)$ & $3(12.5)$ & - & $1(4.16)$ & $4(16)$ & $7(28)$ & $1(4)$ & - \\
\hline & 小 & $\mathrm{D}$ & - & - & $7(26)$ & $1(8.32)$ & $2(8.32)$ & $3(12.5)$ & - & $1(4.16)$ & - & - & $1(4)$ & $5(20)$ & - \\
\hline & & $\mathrm{E}$ & - & $1(3.7)$ & $|1(3.7)|$ & $2(7.4)$ & $1(4.16)$ & $1(4.16)$ & $1(4.16)$ & - & - & 1 (4) & $1(4)$ & 1 (4) & - \\
\hline \multirow{4}{*}{ 眼 } & & i & - & - & - & - & - & - & - & - & - & - & - & - & - \\
\hline & 取 & ii & - & - & - & - & - & - & - & - & - & - & - & - & - \\
\hline & & iii & - & - & - & $3(11.1)$ & $1 \quad(4.16)$ & $1(4.16)$ & $1(4.16)$ & - & - & - & $2(8)$ & 1 (4) & - \\
\hline & 大 & iv & - & - & $2(7.4)$ & $2(7.4)$ & - & $2(8.32)$ & $1(4.16)$ & - & - & 1 (4) & $3(12)$ & - & - \\
\hline 底 & & $\mathbf{v}$ & $1(3.7)$ & $1(3.7)$ & $10(37)$ & $8(29.6)$ & $7(39.1)$ & $5(20.8)$ & $4(16.7)$ & $1(4.16)$ & $1(4.16)$ & $4(16)$ & $6(24)$ & $8(32)$ & - \\
\hline
\end{tabular}




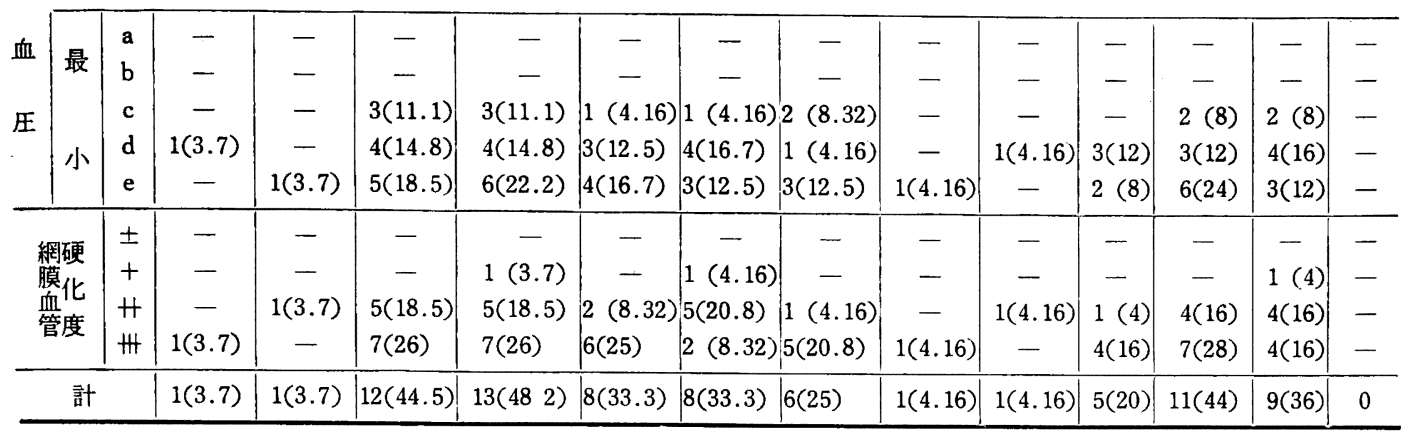

及び平滑と血圧又は網膜血管硬化度との間には拝例数 の少い為特に関係があるとは思われない。

腎全体の老人性萎縮と血圧及び網膜血管硬化度との 間では老人性萎縮の強くなるにつれて全身眼底血圧と むと高い者の数は増加し, 網膜血管硬化度も強い者が 增加する点よりみて, 老人にして血圧高く眼底血管の 硬化の強くなるにつれ老人性萎縮が可なりに存在する ものと思う可きであろろ。

然し良性の真性萎縮腎と全身眼底血圧との間, 或い は網膜血管硬化度との間には全く関係は認められな w。

又腎動脈硬化と全身眼底血圧との間には特に関係は ありとは考えられないが, 最大最小血圧とも高い者に 腎動脈硬化の比較的強い者が多い。又腎動脈硬化と網 膜血管硬化との間には腎動脈硬化のある者は殆んど大 多数は柽度硬化以上の者許りであつたことより, 腎動 脈硬化のある程の者は大多数に網膜血管硬化があると 考えて先つ差支えないと思われる。

d) 剖検時の心電図所見, 心変化と腎変化との関係 (第 19 表)。

直接死因が脳卒中であつた者の生存中の心電図所見 並びに心剖検所見と腎剖検所見其の他を比較するに, 尿蛋白の増加の如何に拘らす心電図所見や冠硬化の程 度, 左心室変化並びに心筋変化との間には特に関係が 認められない。腎の細顆粒萎縮と心電図変化, 心変化 との間にも, 老人性萎縮及び真性萎縮腎と心変化の間 そる殆んど相関はみられない。檑動脈硬化が増加する そつれ, 心筋障害者の例数は増加の道を辿るけれ共, 其の他の心電図所見と腎動脈硬化との間, 又腎動脈硬 化と心所見との間には心筋の混濁所見を除いては特に 関係ある所見はみられない。心筋の混濁が増し，粲動 眽硬化も強い者は例数こそ少いが，この両者間には幾 分の相関がある。

6)病理組織学的に, 網膜血管と略々同径大の心冠
状動脈, 脳内細小動脈及び留実質内の細小動脈を検索 するに, その主変化はいづれも内膜と中膜に主として 存し, 外膜の変化は多くの場合軽度の事が多い。即ち 網膜細動脈飞於ては内膜内被細胞の硝子檥変性と弾力 線維の肥厚, 之に加ろるに脂肪頪粒細胞の出現と軽度 膠原線維の增殖及び肥厚がみられる。時に各線維の変 性が之にまぢるが, 場合によつては多くの場合, 強い 硝子様変性之弾力線維の增殖肥厚が主である事が多 い。中膜では膠原弾力線維の增殖肥厚の他に結合織か 多くの場合に増殖している。然し多くの場合外膜には 変化のない事が多い。

腎細動脈に於ける変化も主に内膜中膜にあるが其の 他外膜にも結合織の増殖を認める場合が嬮々である。 強い変化は内膜の硝子様変性とその肥厚に脂肪顆粒細 胞の出現をみることもある。高度の硝子様変性で内膜 は健康部の数倍にも拡大して管腔が殆んど閉塞されそ ろにみられる事もあつて, かかる場合には単一に染ま つたのが良くみられる事がある。膠原線維と弾力線維 の肥厚の他, 之等の線維の崩壊も認められる。中膜は 全風の半分を占める位迄飞拡大增殖肥厚して膠原弾力 線維の膨化肥厚增殖の他に結合織も著しく増殖して厚 さを著明に增しているが極めて特徽的である。其の 他, 外膜も平常の数倍の厚みを持ち結合織の著しく肥 大しているのがみられ, 血管層の壁の厚さの肥厚に比 して管腔の狭いのが特徴的である。

脳実質内細小血管の病理組織像も亦その特徵的な点 は前 2 者と異ならない。即ち内膜の変化は内被細胞の 肥大と硝子様変性に加うるに弾力膠原線維の肥厚増殖 が著明な他, 所々に脂肪䫷粒細胞の出現を認める他, 中膜にあつては結合織の增殖があると共に弾力膠原線 維が肥厚して壁の厚さが極めて大きくなり, 外膜にも 高度の変化の場合には結合織の增殖が著明にみられ た。尚石灰の沈着は認められなかつた。

心藏に於ける冠状動脈の細小血管に於ける変化は矢 
第 19 表 脳 卒 中者の心所見と

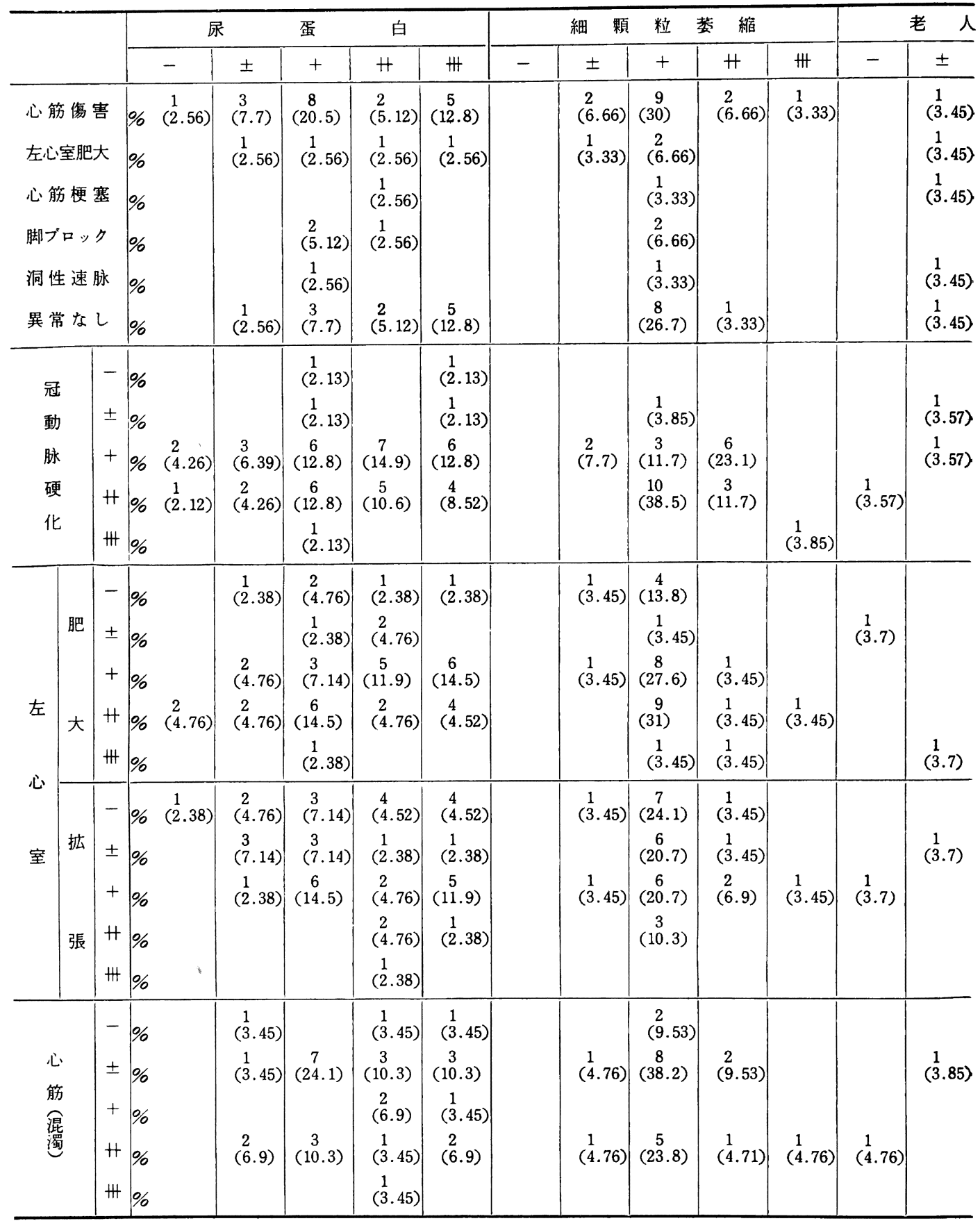


堅所見との関 係

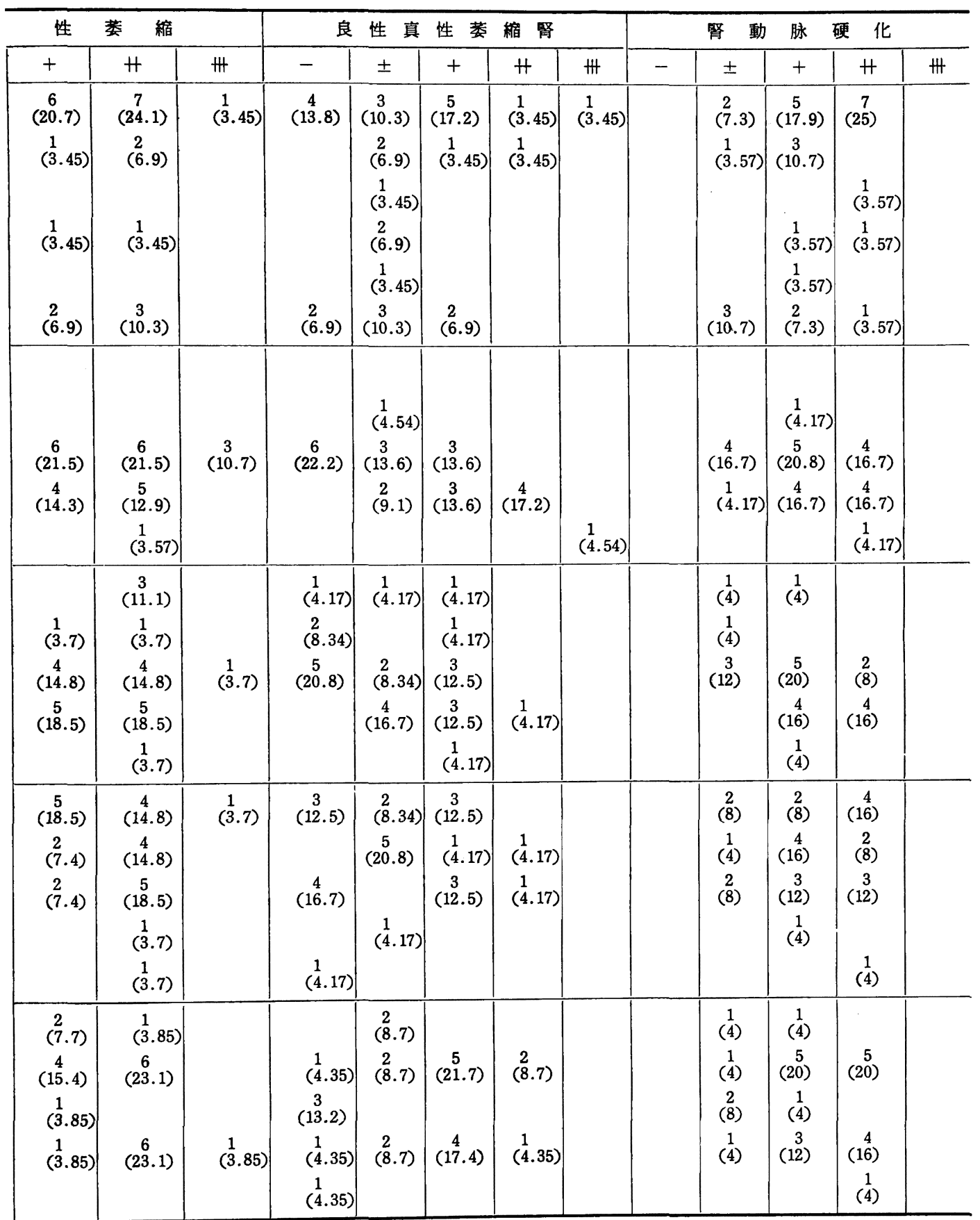


張り前記の場合と略 々同椂である。即ち内膜の硝子様 変性と膠原弾力線維の增殖肥厚飞伴万管腔の細と中 膜飞於ける膠原弾力線維の肥厚増殖並びそ結合織の増 大であり, 更に之に加うるに結合織の肥厚を伴つた外 膜の変化であり, かかる変化は腎実質内細小動脈, 脳 実質内細小動脈の変化と程度の差こそあれ，殆んど同 様の変化であつた。ただ全体的にこの 4 者を比較する といづれの場合に於ても網膜細小動脈の変化は最も軽 微であり, 腎細小動脈の変化は最も強かつたというこ とが言える。

\section{$\mathbf{V}$ 総括並ひに考按}

動脈硬化と高血圧, 並びそ網膜血管硬化度と眼底血 圧の問題を論じた研究は古来数え切れぬ位多数にあ る。然し多くの場合, 高血圧は内科の領域から主とし て論ぜられ，全身の動脈硬化の問題も大部分が内科的 立場から剖検の結果を主として論じられて来た場合が 甚だ多い。近時眼底血管硬化の観察が精密になり, 且 高血圧時に於ける Keith-Wagener and Barker の分 類が眼底所見を中心緾められ而る眼底血圧の計測が 臨床上飞比較的容易飞施行せられるに及んで, 眼科領 域に於ける之等の研究は急速に増加した。然し高年者 を中心とする研究は極めて少く中泉, 小松, 桶渡氏等 の研究の他には特に纆つた発表は見られない。欧洲の Rintelen 氏の研究が恐らく之迄の比較的緾つた論文 ではあるが，それとてす 45 例の少数で而も年令は 30 才より 90 才迄で 30 才以上の高年者は 33 例飞過ぎな い。又眼底血管眼底血圧と腎変化, 或いは心変化, 或 いは脳血管の変化との関係を夫々 2 者づつで論じた論 文は桶渡教授並びそその門下や石川氏等に見受けられ るが，心，監，脳，眼とこの 4 者間の関連性を眼科領 域より高年者のみに就いて論じた研究は皆無である。 長年月飞亘る剖検記録と生前の検査項目等では前と後 で相当の差異が認められる結果, 統計例数汇多少の相 異が認められた。

心腎脳眼を眼を中心として心疾患死亡者と脳矮患死 亡者に就いて詳細な統計の中の一部分であるが，関連 性の有無を検討する事にした。

高年者の年令別性別の構成分布では 70 才が圧倒的 そ多く, 全症例の半数以上を占めて居り, 性別では女 子がほぼ男子の 2 倍を示めしているが，之はいづれの 論文の統計の場合でも大体その様である。

高年者は年令と俱全身の抵抗力が弱まつているか ら臨床的診断と剖検による直接死因とが必らずしも一 致せぬことは屡々である。例えば臨床的脳卒中では，
あつても之が長引けば直接死因としては肺炎という如 きヶースは屡々認められる所であつて，私の直接死因 別統計では心疾患忙よる死亡が最も多く全体の $28 \%$ 以上を占め, 次いで肺疾患, 就中肺炎飞よる死亡が最 多であり，脳疾患による死亡は $15.9 \%$ であるが癌に よる死亡が308例中 34 例もあつて,可なりの高率を示し ている。然し腎疾患による死亡は 1 例も認められず, この事は老人には腎萎縮や硬化が多いに拘らず直接腎 疾思が致命的になる様な者がない事を示すと共に，腎 疾患による死亡は多くは 60 才代迄に終つて仕舞うこ とを明白示したものとして興味深く，矢張り高年者の 死因では，心，脳，肺疾患や癌が重大な意味を持つも のと考えられよう。

心電図の上では ST 波の低下， T波の逆転が心筋の 器質的変化を意味することは既飞周知の事実である が, 心電図撮影の 202 例中, 生前飞脳血管飞異常があ ると臨床的に診断された者の中で心電図に異常を認め た者は 76 例, 約 $1 / 3$ 飞近い。心電図には異常あるも 脳血管には特に障害の無いと思われていた者は 52 例 であり，心電図学的にも又臨床的飞脳血管飞も障害の なかつた者は僅か 37 例である。即ち高年者になれば 心電図の上でも又臨床的にみても脳血管に何等かの変 化が多少とる認められるすのであることを知るわけで あるが，高年者の中にはそれで心，脳ともに全く異常 なく高血圧も無い者が 28 例もある事もは注目す可き 点であろろ。

心疾患による死亡は 87 例で之等の死因は心筇障 害, 心不全, 心筋梗塞, 心衰弱, 心破裂であるが長生 きする程の者には心筋梗塞や心筋障害によるより，心 不全や心衰弱で死亡する者の多い事は一般て言われて いる通りである。而してたとえ心障害で死亡している 程の者でも脳卒中や脳血管硬化症の明白にみられる者 （43 例） と生存中脳血管障害を認められなかつた者 （44例）はほぼ相半ばして居る。即ち高年者は脳血管 そる心電図にも異常を認める者が然らざる者の 3 倍近 くも存在することになるし，脳血管に異常があるか， 或は心電図に異常があるか，どちらか何等かのい及 で異常のある者は全く心脳任異常の無かつた者の実に 倍近くにす存在するということになるわけである。

高年者は一般に多かれ少なかれ，網膜血管飞硬化性 変化を有する者が多い。この硬化性変化飞就いては既 飞中泉, 小松, 桶渡氏等の詳細な報告があり, 網膜静 脈の緊張蛇行, 中心動脈の壁の混濁肥厚や血柱反射の 状況，動静脈径比や，交叉現象としての Salus 交叉弓 
Gunn 現象があり，出血白斑や網膜周辺部の震状変性 等も参考されているが，著者は樋渡教授の分類方法を 利用した。尚眼底血圧の分類の仕方及び全身血圧の分 類方法は之迄に村上教授, 関博士等の全身血圧分類法 と樋渡教授の眼底血圧分類法を採用した事は，一般に 老人に於ける血圧が何等の降圧剤を用いないとも拘ら ず極めて動㩰の幅の大きい事及び眼底血圧も之に応 じ，而も全身血圧程ではないが可なりの幅で動摇する すのであるからである。その結果，心疾患で死亡した 者の蹦床的脳血管の変化と全身血圧眼底血圧及び網膜 血管硬化度を比較してみると, 脳血管に傷害があると 診断された者は悉くが網膜血管硬化が中等度以上であ り，たと兄生存中脳血管障害を起さなかつた者でも血 圧六進のあつた者は眼底血管の硬化が悉く強い者の及 であつたことは，全身眼底両血圧の場合全く同傾向で あり，臨床的脳血管障害と眼底所見及び血圧が極めて 密接な関係を示するのとして注目す可き点である。而 してその時の剖検結果による脳の太い血管所見（基 底, 前脳, 中脳, 後脳動脈) と眼底血管硬化度及び血 圧の関係では, 脳基底動脈, 中脳動脈の硬化度飞次い で, 後脳動脈の硬化度が大体平行し, 前脳動脈の硬化 とは余り関係のない事を知る事が出来る。

高年者の腎は一般飞或程度の老人性萎縮及び良性の

腎萎縮を示めし，或程度の尿蛋白を証明する者が多い のであるが，この場合には，尿蛋白の陽性陰性如何飞 拘らず眼底血管の硬化は中等度以上が大多数であり， たと蛋白陰性でも全身眼底両血圧は高い者が多い傾 向を示しているし，蛋白陽性度（\#）の部では眼底血 圧高く眼底血管硬化の高度のすのが圧倒的多数である が敩密にいつて平行的関係は認められない。事実, 実 際に剖検した腎所見と血圧並びて眼底所見を比較して みると, 全身血圧, 眼底血圧, 眼底血管硬化度の増大 とつれて各種の萎縮度が強大になつてゆくという傾向 は殆んど認められず，又良性腎萎縮でも同様の傾向に めり, 粲動脈硬化度の強い程の者は眼底血管の硬化の 強い者が極めて多いが，血圧とは余り関係がない様で ある。尚剖検時の肉眼的所見飞よる腎細顆粒萎縮は細 小動脈の硬化飞基因する結果として表現され, 粗大顆 粒萎縮は小動眽硬化の結果であると一般に表現される 事は周知の所である。而してこの事実は, 直接死因が 脳血管障害による死亡者の場合に於ても全く同様であ つて, 直接死因が，心，脳いつれの場合でる腎萎縮度 と血圧並びそ眼底血管硬化度との間には関連性が薄い と考えられるが，唯脳血管障害死亡者群では眼底所見
及び血圧と腎動脈硬化度との間飞は心疾患死亡者の夫 れよりも可なり密接な関係を見出し得る（第 17 表， 第 18 表参照)。既述の如く尿蛋白の場合，心疾患死亡 者に比して，脳血管障害で死亡した者の場合は第16表 飞見る如く，蛋白陽性者が増加するとつれ，眼底血管 の硬化強く且つ全身眼底両血圧俱飞高い者が増加して 居り,この場合には或程度の相関があり，従つて心疾 患死亡者飞比し脳疾患死亡者の腎と眼との関係は明白 そ差異を認めるといえよう。而してこの結果は大戸， 斎藤両氏及び樋渡教授の之迄の結果と略々同一の成續 を示めした事になる。

心疾患で死亡した者を剖検してその脳血管の硬化と 腎所見を肉眼的飞比較してみると，腎細顆粒萎縮と中 脳動脈の硬化, 或いは腎動脈硬化と基底中脳両動脈の 間では硬化度の増加が例数的に平行している傾向がる られる。

心電図を私は 177 例飞就いて検討した結果, 単一の 傷害のみでなく，老人には各種の心障害を合併してい る者が可なりの数にあるが又一方高年になつても心電 図に全く異常を認めない者が 4096 亿るふぶ事は極め て注目に值する所である。而して直接脳疾患で死亡し た 49 例は心電図の変化の有無に拘らす眼底血管硬化 度は殆んど大部分が中等度硬化以上であり又眼底血圧 も高い者が多く発見せられたし，冠動脈硬化陰性の者 も極めて少い。然し冠動脈の狭窄と閉塞は血圧及び眼 底所見とは全く関係はない様であり，心室の肥大は血 圧眼底所見と或程度の平行的関係はあるが，拡張は関 係なしといえそ万である。又心筋の混濁は，之の強い ものと血圧が高く又眼底所見の強いものが割合として は多いが，胼胝壊死，梗塞との間には全く関係がな w。

脳卒中死者の心所見と腎所見との比較は特に両者の 変化の間飞密接な関係を見出し得なかつた。唯尿蛋白 強陽性の者には冠硬化の強い者或いは左心室肥大の者 が多いという程度に過ぎない。

然し大脳実質中, 或いは腎実質中の細小動脈や, 冠 動脈で, 網膜中心動脈と略々同径大の動脈の病理組織 像を検討するとそこに極めて注目す可き結果が得られ た。即ち硬化は網膜細小動脈では変化が主に中膜と内 膜にあって, 外膜の変化は極めて程度が軽いが, 他の 3 者飞於ては中膜内膜の変化飞加觉て外膜にも可なり の変化があり, 結合織の増殖肥厚している様子がみら れた。而もいつれの場合に於ても同一人の組織像に於 ては腎細小動脈の変化が最も強く, 綢膜細小動脈の変 
$-254-(1124)$

化は最も軽微であり、この中間に脳細小動脈, 或いは 冠動脈の硬化あるすのが位置する様な結果であつた。 従つて脳実質内細小動脈と冠動脈の硬化はいづれが強 くとも筒細小動脈及び網膜細小動脈硬化の中間飞位す る事が判明したわけであり，この点から考えれば，網 膜中心動脈江硬化があれば，之と同等か或いはそれ以 上の硬化性変化が冠動脈, 脳細小動脈及び啃細小動眽 飞存在すると考えて先つ間違いないと想像される。

\section{VI 結 論}

60 才以上の高年者 308 例の全身眼底両血圧網膜血 管の硬化度を脳実質内細小血管及び各種脳動脈, 腎細 小動脈及び冠状動哌の変化並びに剖検所見と比較検討 した結果，次の如き結論を得た。

1）剖検による直接 の 死因は心疾患によるもの 87 例 $(28.2 \%)$, 脳疾患によるすの 49 例 (15.9\%) で, 腎疾患による死亡者は認められなかつた。

2）直接死因が心疾患の者で，臨床的に脳血管に障 害ある者のその変化と眼底所見と全身眼底血圧との間 飞は極めて密接な関係があり, 殊飞脳基底動脈, 中脳 動眽と眼底所見眼底血圧の間に著明な相関々係を認め た。

3）直接死因が心疾患の者で，臨床的に脳血管障害 があるとされた者の脳血管と腎諸変化との関係では, 実際飞脳血管に障害のあつた者と腎動脈硬化との間飞 は, 然らざる者に比較して, 明らかに密接な平行関係 を認め得た。

4）眼底血管飞硬化があり, 眼底血圧が高くなるに つれて心電図上にる異常を認める者の数が増加する。

5）臨床的に脳血管障害ありとされた者と眼底血管 硬化, 全身眼底両血圧とは密接な関係がある。

6）直接死因が脑疾㭧の者の全身眼底両血圧及び眼 底所見と心電図所見との関係は脳血管と全身眼底両血 圧及び眼底所見との関係程には密接ではない。

7）脳疾患による死亡者の眼底所見, 全身眼底両血 圧と腎所見との関係は，心疾患死亡者の腎所見と眼底 所見全身眼底両血圧に比して前者が密接な関係を示め している。

8）直接死因が脳疾㭧にある者の心電図，心変化と 腎所見との関係では，心電図に変化のある者に㛑動脈 硬化の強い者が増加している。

9）病理組織学的に注同径大の眼底血管，心冠状 動脈, 腎細小動脈之脳実質内細小動脈では硬化の強さ は, 同一人に於てはいつうれの場合飞す留細小動眽硬化 が最高で眼底細小動眽硬化は最低であつた。硬化は
腎，脑，心，眼底血管の䐓に弱くなるが，脳細小血管 之冠動脈では逆の場合もあつた。

擱筆にあたり終始御留切な御指導と御校閲を頂いた恩師桶 渡教授に满腔の感謝を捧げると俱に御援助を頂いた日本医大 附属医院眼科医局の諸先生に厚く御礼申上げる。又御校閲を 頂いた馬詰教授に感謝致します。

文

1) F. Rinteln : Bibliotheca Ophth., 29, 別冊 1 5(1939)

2) Bailliart et Magitot : Ann. d'Ocul., 166, 271 (1929), Zbl. f. ges. Oph., 5, 442(1921), 16, 92(1922), 21, 462 (1929)

3) Bliedung : Arch. f. Aug., 94, 214 (1924)

4) Rasvan : Zbl. f. ges. Oph., 18, 28 (1927)

5) Lebensohn : Zbl. f. ges. Oph., 16, 226 (1925)

6) Salvati : Zbl. f. ges., 7, 307, 516, (1922)

7) Espildora : Zbl. f. ges Oph., 26, 74, 200, 415, 752, 753 (1932), 27, 170 (1932), 37, 320 (1936)

8) Marcolongo : Zbl. f. ges. Oph., 28, 748 (1933)

9) Baurmann : Arch. f. Oph., 118, 118 (1927), 124, 693 (1930)

10) Weiss u. Horine : Arch. of. Oph., 6, 535 (1931)

11) Schieck : Zbl. Oph., 5, 172415 (1921) 21, 1 (1929)

12) Schiötz : Arch. f. Aug., 62, 317 (1909)

13) Brückner : Kurzes Handb., (1932)

14）井街謙, 小泊重比子：日眼, 38, 1051 (1934)

15）植村操, 菅沼定男: 日眼, 38, 1835 (1934), 日眼 40, (1936)

16）長谷部俊連 : 日眼，40，318(1936), 日眼 41，93 (1937)

17）鴨川 章: 日眼, 41, 111 (1937)

18）鬼怒川親雄 : 東北医誌, 21，688（1937）

19）北堀省吾 : 日眼，32，389 (1927)

20) 進藤真作 : 実眼, 13，229 (1930)

21）飯塚左右二：日眼，38，1074 (1934)

22）庄司義治, 鈴木新助 : 日眼, 35, 371 (1931)

23）小松弘邦: 日眼, 47, 641 (1943)

24）関 盛光: 浴風園紀要, 19, 47 (1947)

25）中沢修正：浴風園紀要, 10, 1 (1931)

26）小柳美三：眼と高血圧，(克誠堂）(1941)

27) Friedenwald : Zbl. f. ges. Oph., 22, 633 (1930)

28) Sallmann : Zeit. f. Aug., 57, 386 (1925)

29) 梶 利一: 日眼, 48, 425 (1944)

30) Volhard : Zbl. f. ges. Oph., 21, 129 (1929) Handb. d. inn med., 2 Aug (1931)

31）木村男也, 松岡茂：日病誌, 381385 (1938)

32) Barana Rotonai : Kl. Mbl. f. Aug., 705 (1934)

33）中泉行正 : 日眼, 41, 648 (1947)

34) Thiel : Zbl. f. ges. Oph., 22, 31 (1930)

35) Bardsley : Brit. o. Oph., 1, 239 (1917)

36) Salus : Kli. Mbl. f. Aug., 82, 471 (1929)

37) Guist : Zeit. f. Aug., 73, 232 (1921)

38）鹿野信一：眼臨, 40, 232 (1946)

39) Horine u. Weiss : Arch. o. Oph., 6, 535 (1931)

40) 樋渡正五：臨眼， B， 466 (1952), 日眼, 57, 479 (1953), 日眼, 58, 1313 (1954), 老年病, 1, 75 (1957), 日眼, B1, 1364 (1957), 日眼, 62, 1138 (1958), 内科, 1, 346 (1958)., 保険医学誌, 58, 27 (1960) 
41) 大戸 建 : 日医大誌, 27, 1138 (1960)

42）斉藤紀美子：日医大誌, 27，1149 (1960)

43）大戸建，斉藤紀美子：日眼，64，1759 (1960)

44) 加藤 謙: 日仏医，3，1 (1956)，臨眼，9，476，1310 (1955), 最新医学, 11, 833 (1956)
45) 渡辺蓮太郎 : 名古屋医学, 17, 1011 (1959)

46）小島 温: 日公衆衛，6，64 (1959)

47) 新井宏明 : 最新医学, 14, 1114 (1959)

48) 桶渡正五: 最新医学, 12, 683 (1957), 日眼, 64, 1973 (1960)

\section{韋論文付図}

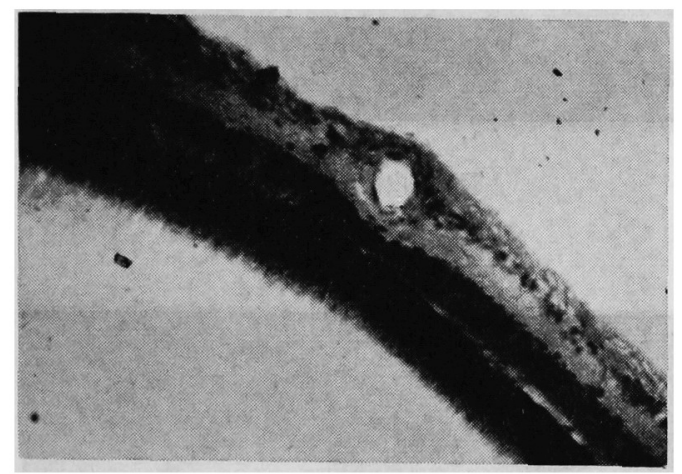

第 1 図症例 11

網膜血管硬化像

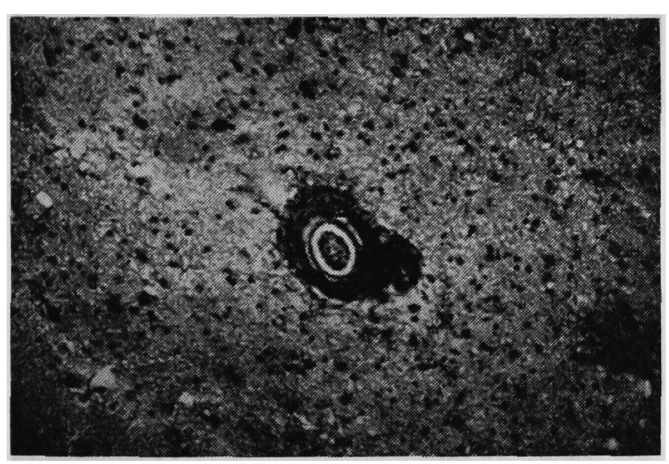

第 2 図 症例 11

脳実質内細小動脈の硬化図

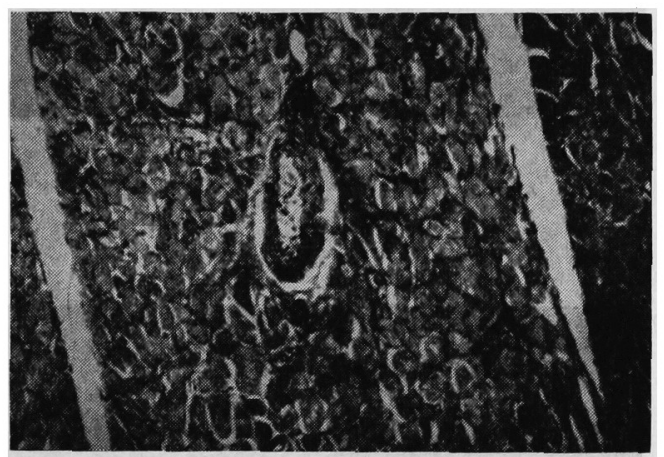

第3図 症例 11 心冠動脈細小の硬化図

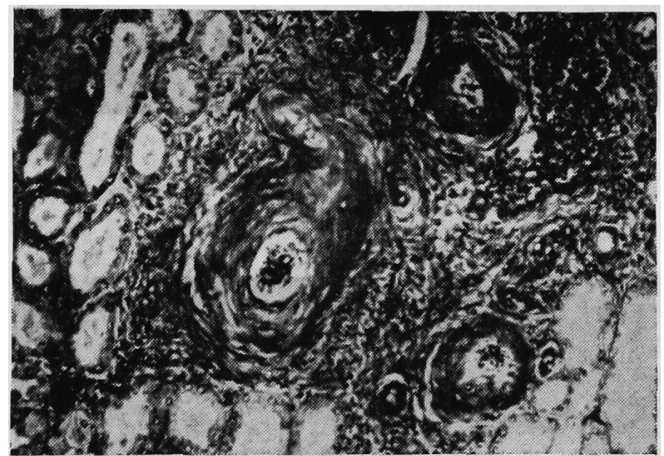

第 4 図 症例 11

腎実質内細小動脈の硬化図 


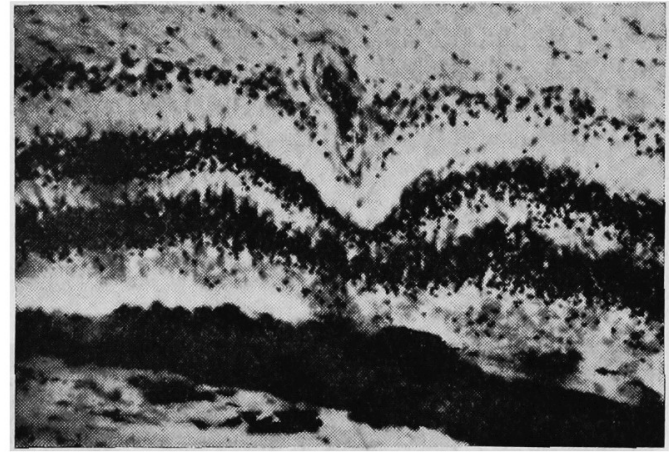

第 5 図症例 34

細膜中心動脈の硬化図

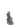

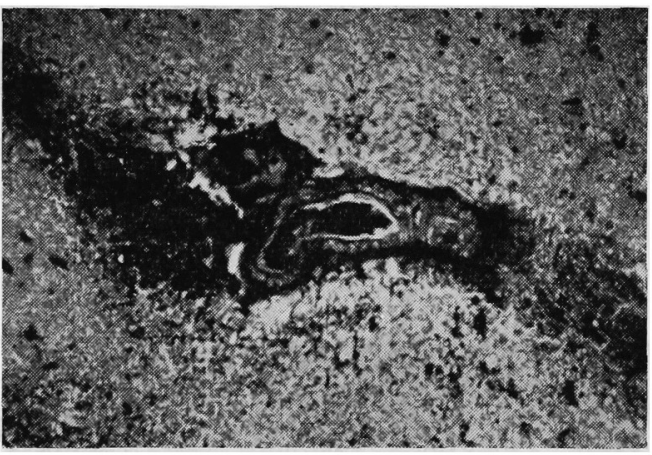

第 6 図症例 34

脳内細小動脈の硬化図と出血巣

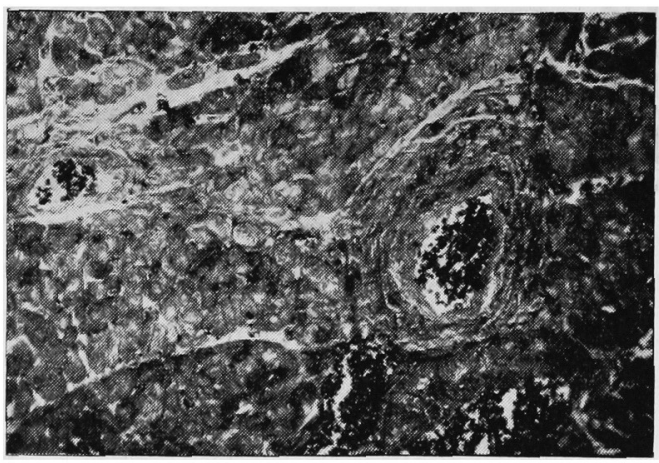

第 7 図症例 34

心冠状動脈の硬化像

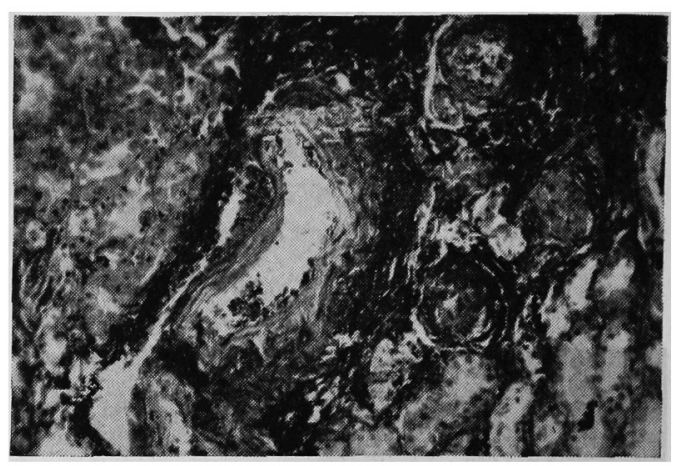

第 8 図症例 34

腎実質内細小動脈の硬化図

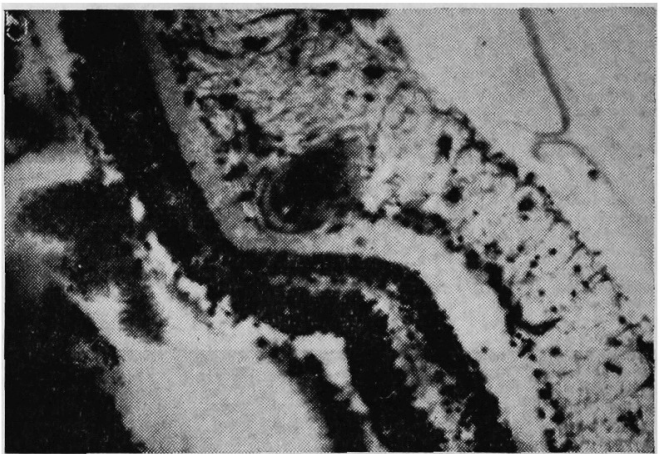

第 9 図 症例 50

網膜中心血管の硬化図

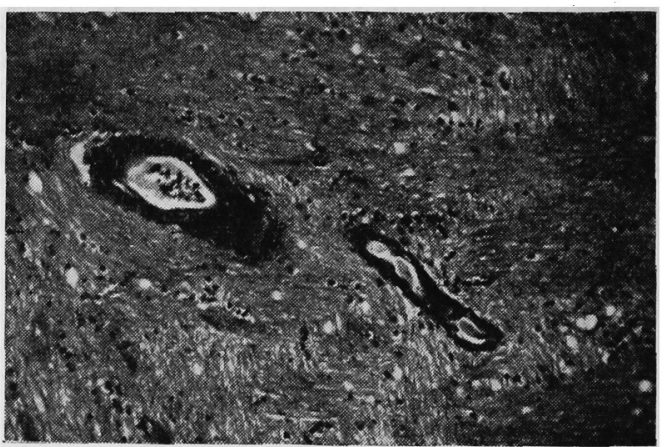

第 10 図症例 50

脳実質内細小動脈の硬化図 


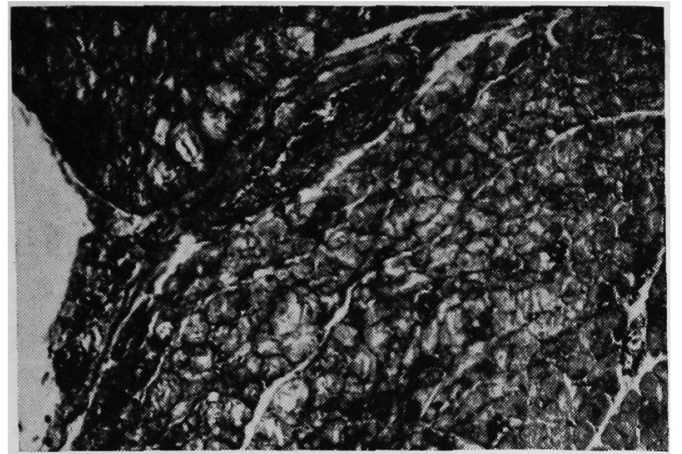

第 11 図症例 50

心冠状動脈細小血管の硬化図

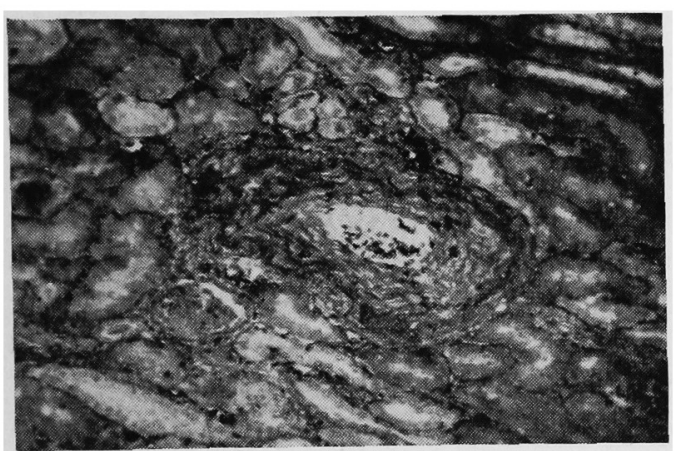

第 12 図症例 50

腎実質内細小動脈の硬化図

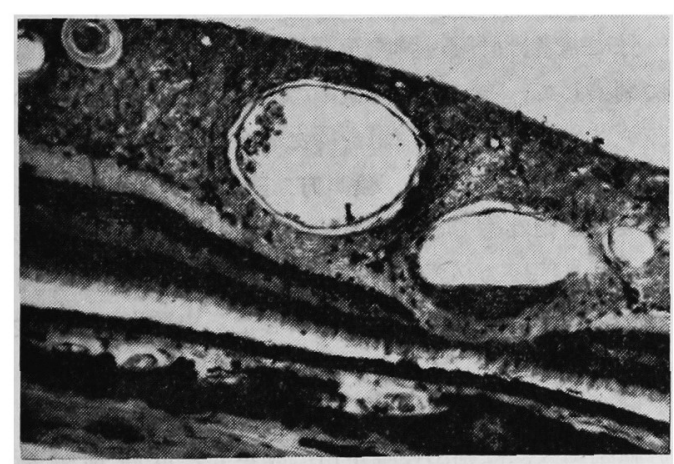

第 13 図症例 122 網膜中心動脈の硬化図

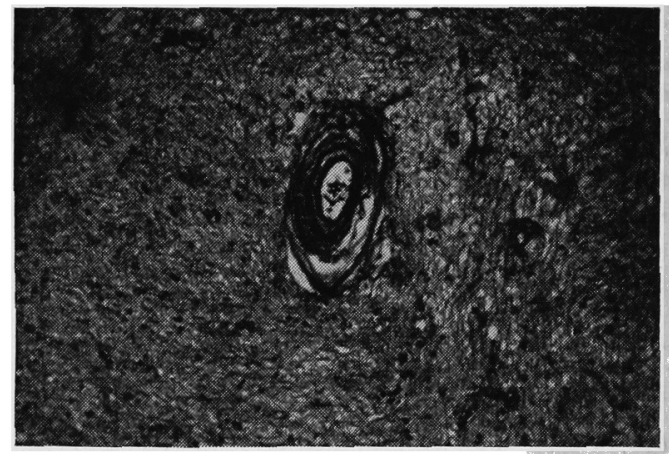

第 14 図症例 122

脳内細小動脈の硬化図

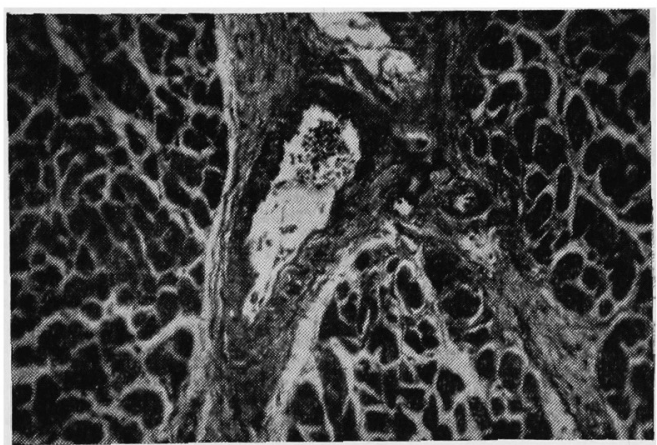

第 15 図症例 122

心冠状細小動脈の硬化図

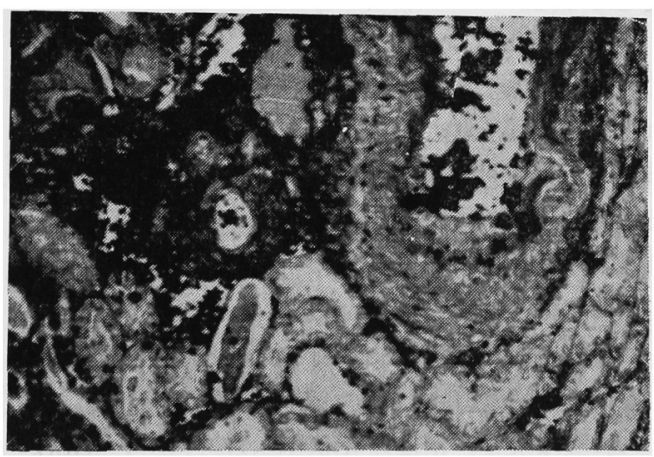

第 16 図症例 122

腎細小動脈の硬化図 